\title{
PHYSICAL PROPERTIES OF ELECTRICALLY WELDED STEEL TUBING
}

\author{
By H. L. Whittemore, J. S. Adelson, ${ }^{1}$ and E. O. Seaquist
}

\section{ABSTRACT}

This investigation was made for the purpose of determining the physical properties of tubing made from sheet steel in which the longitudinal seam was welded under pressure by the electrical-resistance method.

Tubes ranging in outside diameter from five-eighth inch to 3 inches and in wall thickness from 0.028 to 0.120 inch, inclusive, were tested in numerous ways to show the strength of the tube and the strength of the weld.

With a variation of cold working a wide range of strengths were obtained without appreciable change in the carbon content of the steel. Most of the tubes were made from mild steel containing about 0.08 per cent carbon, and a few were made from steel containing about 0.25 per cent carbon.

The average tensile strength of the tubes in full section varied from 54,000 lbs./in. ${ }^{2}$ for the as-welded tubes to $74,000 \mathrm{lbs}$./in. ${ }^{2}$ for the hard-rolled tubes, and the compressive strengths in the axial crushing test of specimens $2 \frac{1}{2}$ inches long were practically the same.

The welds were tested in (1) the hydrostatic test, (2) the tensile test of the welds in circumferential strips, (3) the torsion test, and (4) the axial crushing test.

In the hydrostatic test, excepting the annealed tubes, only 1 of the 30 specimens fractured in the weld, but this at a high bursting strength. Only one of the six annealed specimens fractured outside of the weld. This showed that the annealing process reduced the strength of the weld about 10 per cent below that of the base metal.

In the tensile test of the welds in circumferential strips of 2 -inch tubes the longitudinal tensile strength was reached with no fractures in the welds except the annealed tubss. The strength of the weld of the annealed specimens was about 93 per cent of the strength of the base metal as determined by testing strips with the weld outside of the reduced section.

In the torsion test none of the tubes showed any fracture in the weld or in the base metal when the twisting was continued after the ultimate torque was reached. The average shearing stress in the extreme fiber at the proportional limit was, for swaged tubes, 22,610 lbs./in.2, for rolled tubes 22,190 lbs./in.2, and for hard-rolled tubes 30,310 lbs./in. ${ }^{2}$.

In the axial crushing test the weld was shown to have the strength and ductility to fold evenly with the base metal. There were a few exceptions in which cracks showed at the weld in the outer edges of the folds.

Except in the case of swaged-annealed tubing, the properties of the base metal (the metal not affected by the welding operation) can be used in determining the working stresses for different structural uses of tubing made by the process used in the manufacture of this electrically welded tubing, no allowance being necessary for the altered structure in and adjacent to the weld. The properties at and near the weld for annealed tubing are sometimes slightly lower than the properties for the base metal.

\section{CONTENTS}

I. Introduction

II. Purpose of the investigation

III. Acknowledgments

IV. Description of tubing

1. Material.

2. Method of manufacture.

(a) Types of treatment

(1) As welded

(2) Cut burr

(3) Swaged. 
IV. Description of tubing-Continued.

2. Method of manufacture-Continued.

(a) Types of treatment-Continued.

(4) Rolled

(5) Hard rolled

(6) Annealed.

V. Methods of testing and results

1. Diameter and thickness of wall

2. Tensile test of full section

3. Axial crushing test

4. Torsion test

485

5. Hydrostatic test

6. Tensile test of weld

7. Hardness

8. Flanging test

9. Microscopic examination

VI. Discussion

1. Variation of outside diameter

2. Variation of thickness of wall

3. Tensile test of full section.

4. Axial crushing test

5. Torsion test

6. Hydrostatic test

7. Tensile test of weld

8. Hardness

9. Flanging test

\section{INTRODUCTION}

For many of our industrial processes tubes and pipes are used to convey liquids and gases. They are used in large quantities for the distribution of water and gas in our cities, and for pipe lines across the country to bring oil and gas to manufacturing and shipping centers. Tubing is used in many industrial applications where high pressures are applied externally as well as internally. In department stores tubing is used for pneumatic-conveyor systems and in factories for the rollers in roller conveyors. It is used for conduit for electric wiring. In automobiles it is used for driving shafts, steering columns, water manifolds, and exhaust pipes.

From a theoretical standpoint there are, in many cases, advantages in using tubes as structural members and as parts of machines instead of using other cross sections. In the past, however, the high cost of tubing has limited its use, frequently making it more economical to use rolled sections having greater weight.

If the member is subjected to tensile stresses only, the crosssectional area and, therefore, the weight are the same whether it is solid or tubular. For some conditions the tubular member is to be preferred because it is less likely to vibrate.

If the member is subjected to compressive stresses, as in a strut or column, a tubular member is efficient because for a given crosssectional area the moment of inertia of a circular tube is the same about all centroidal axes, and it is relatively high.

When long columns fabricated from rolled shapes fail, they often fail by twisting if the torsional rigidity is low. Tubular columns, which have a relatively higher torsional rigidity than any other commercial form, probably never fail by twisting.

If the member is subjected to transverse loads, as in a beam, a comparison of the strengths of tubular and other sections can only be made after the section moduli have been computed. In general, 
higher section moduli and moments of inertia can be realized practically with tubes than with rolled sections except when a large difference is desired in two different planes, as in a narrow I beam.

When subjected to twisting couples, as in shafts for the transmission of power, a tube is stronger for the same weight than a solid cylindrical shaft or other cross section.

If the member in service is accidentally subjected to unexpected local forces, tubes will in many cases prove more satisfactory than structural shapes, because tubes have no unsupported flanges to be damaged.

Steel tubing is used almost exclusively to form the fuselage structures of airplanes. This is an example of a structure designed to obtain the greatest strength for a given weight.

In the past it has been difficult and expensive to join tubular members of a structure by rivets or fittings, but during the past few years fusion welding has come into extensive use for fabricating structures and machines.

It is believed that tubes can be welded more satisfactorily than rolled shapes because the wall of the tube is somewhat thinner, the thickness is more nearly the same for all members, and the surface of tubes is convex. ${ }^{2}$

In the past, tubing of the desired material and dimensions has not always been available commercially, or if available, the price has been prohibitive. As the cost of tubing decreases, due to improvements in the method of manufacture, the use of tubes for the members of small machines and light structures should increase.

That structures fabricated from tubes having welded longitudinal seams possess the advantages which have been outlined is shown by tests recently made in Germany ${ }^{3}$ of towers for electrical transmission lines.

These specimens consisted of four vertical members connected by diagonal lattices. Some were fabricated from steel tubes having welded longitudinal seams, the connections being made by oxyacetylene welding. Other specimens of the same dimensions were fabricated from rolled angles, the connections being made by riveting.

The specimens were $6 \mathrm{~m}$ (19.68 feet) and $12 \mathrm{~m}$ (39.37 feet) high. The base was anchored to a foundation and the horizontal force at the top increased until the tower failed.

The efficiency of the towers at maximum load computed on the weight of the towers was, for the $6 \mathrm{~m}$ towers, angle-iron tower 1 , tubular tower 2.07, and for the $12 \mathrm{~m}$ towers, angle-iron tower 1, tubular tower 1.66.

The report concludes that thin tubes having a welded longitudinal seam, which is comparatively cheap, can be used successfully instead of rolled sections.

Tubular towers are especially desirable if freight rates are high or if the pressure on the soil must be low.

Tubular towers offer less wind resistance and have a better appearance than towers fabricated from rolled sections or reinforced concrete.

2 "Strength of Welded Joints in Tubular Members for Aircraft" will be published at an early date as a Technical Note of the National Advisory Committee for Aeronautics, Washington, D. C.

${ }^{3}$ A. Hilpert and O. Bondy, Berlin-Charlottenburg. Zeitschrift des Vereines Deutscher Ingenieure, 73, No. 24, p. 805; June 15, 1929. 


\section{PURPOSE OF THE INVESTIGATION}

Tubes made from sheet or strip steel, with the longitudinal seam electrically welded, are being used commercially. As there is little information on the strength and other properties of these tubes, the Bureau of Standards, in cooperation with Steel \& Tubes (Inc.), has made the present investigation to determine the physical properties of electrically welded tubing. It is hoped that the investigation will enable designers of structures and machines to use welded tubes economically under tensile loads and under compressive loads on short lengths, as in aircraft; under torsional load, as in steering columns and drive shafts of automobiles; under internal pressure, as in pumps and jacks; and for flanged connection, as in exhaust pipes for gasoline engines. Tests have been made to determine (1) variations in diameter and in thickness of wall; (2) the modulus of elasticity, proportional limit, yield point, tensile strength, and elongation of full section; (3) the axial crushing strength; (4) the torsional modulus of elasticity, and torque at elastic limit and ultimate torque; (5) the bursting strength under hydrostatic pressure; (6) the tensile strength of the weld; (7) the hardness (Rockwell number); (8) the suitability for flanging; and (9) the microscopic structure of the weld.

The results obtained from the axial crushing tests, the bursting tests, the tensile tests of the weld, and the flanging tests depended greatly upon the strength and ductility of the welds.

\section{ACKNOWLEDGMENTS}

Steel \& Tubes (Inc.), cooperated in this investigation by furnishing all the tubing and assisting in the tests.

The chemical analyses were made by R. M. Fowler, of the chemistry division. The microscopic examinations were made by C. E. Eggenschwiler, of the metallurgical division.

\section{DESCRIPTION OF TUBING}

\section{MATERIAL}

Typical chemical analyses, shown in Table 1 , indicate that most of these tubes are mild steel containing about 0.08 per cent carbon. This tubing is also made in higher carbon steels, such as S. A. E. 1025, examples of which are tubes Nos. 85 and 86 .

The manufacturer states that all tubes were made from boxannealed cold-rolled strip steel with the exception of some of the heavier gage tubes which were made from pickled hot-rolled strip steel, examples of which are tubes Nos. 58, 84, and 85.

The sizes, thicknesses of wall, and types of treatment of all the tubes are shown in Table 2. 
TABLE 1.-Chemical analysis

\begin{tabular}{|c|c|c|c|c|c|}
\hline Tube No. & Carbon & Manganese & Phosphorus & Sulphur & Silicon \\
\hline $\begin{array}{l}7 \\
10 \\
13 \\
31 \\
31\end{array}$ & $\begin{array}{r}\text { Per cent } \\
0.08 \\
.09 \\
.08 \\
.06 \\
.05\end{array}$ & $\begin{array}{r}\text { Per cent } \\
0.33 \\
.43 \\
.43 \\
.36 \\
.33\end{array}$ & $\begin{array}{r}\text { Per cent } \\
0.010 \\
.010 \\
.010 \\
.010 \\
.015\end{array}$ & $\begin{array}{r}\text { Per cent } \\
0.030 \\
.030 \\
.030 \\
.030 \\
.025\end{array}$ & $\begin{array}{r}\text { Per cent } \\
<0.01 \\
<.01 \\
<.01 \\
<.01 \\
<.01\end{array}$ \\
\hline 63 & $\begin{array}{l}.05 \\
.05 \\
.05 \\
.06 \\
.05\end{array}$ & $\begin{array}{r}.37 \\
.33 \\
.40 \\
.37 \\
.31\end{array}$ & $\begin{array}{l}.010 \\
.010 \\
.015 \\
.010 \\
.010\end{array}$ & $\begin{array}{l}.025 \\
.020 \\
.035 \\
.025 \\
.020\end{array}$ & $\begin{array}{l}<.01 \\
<.01 \\
<.01 \\
<.01 \\
<.01\end{array}$ \\
\hline 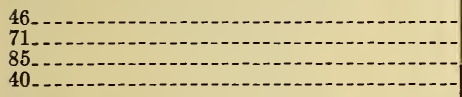 & $\begin{array}{l}.04 \\
.07 \\
.23 \\
.09\end{array}$ & $\begin{array}{l}.36 \\
.34 \\
.47 \\
.41\end{array}$ & $\begin{array}{l}.015 \\
.010 \\
.020 \\
.025\end{array}$ & $\begin{array}{l}.050 \\
.030 \\
.030 \\
.053\end{array}$ & $\begin{array}{l}<.01 \\
<.01 \\
<.02 \\
<.01\end{array}$ \\
\hline 64 64 & $\begin{array}{l}.11 \\
.09 \\
.07 \\
.07\end{array}$ & $\begin{array}{l}.41 \\
.38 \\
.40 \\
.36\end{array}$ & $\begin{array}{l}.026 \\
.013 \\
.016 \\
.010\end{array}$ & $\begin{array}{l}.052 \\
.040 \\
.050 \\
.023\end{array}$ & $\begin{array}{l}<.01 \\
<.01 \\
<.01 \\
<.01\end{array}$ \\
\hline $\begin{array}{l}86 \\
98 \\
104 \\
107\end{array}$ & $\begin{array}{l}.25 \\
.05 \\
.11 \\
.08\end{array}$ & $\begin{array}{l}.42 \\
.37 \\
.44 \\
.40\end{array}$ & $\begin{array}{l}.011 \\
.013 \\
.014 \\
.020\end{array}$ & $\begin{array}{l}.022 \\
.030 \\
.045 \\
.044\end{array}$ & $\begin{array}{l}<.01 \\
<.01 \\
<.01 \\
<.01\end{array}$ \\
\hline
\end{tabular}

TABLE 2.-Results from tensile, hardness, and axial crushing tests

\begin{tabular}{|c|c|c|c|c|c|c|c|c|c|c|c|}
\hline \multirow{3}{*}{ Tube No. } & \multirow{3}{*}{$\begin{array}{l}\text { Type } \\
\text { of } \\
\text { treat- } \\
\text { ment }\end{array}$} & \multicolumn{2}{|c|}{ Nominal size } & \multicolumn{2}{|c|}{ Wall thickness } & \multicolumn{4}{|c|}{ Tensile test of full section } & \multirow{3}{*}{$\begin{array}{c}\text { Rock- } \\
\text { well } \\
\text { num- } \\
\text { ber, } \\
116- \\
\text { inch } \\
\text { ball, } \\
\text { 100-kg } \\
\text { load }\end{array}$} & \multirow{3}{*}{$\begin{array}{c}\text { Axial } \\
\text { crushing } \\
\text { test } \\
\text { (ulti- } \\
\text { mate } \\
\text { strength) }\end{array}$} \\
\hline & & \multirow{2}{*}{$\begin{array}{c}\text { Out- } \\
\text { side } \\
\text { diam- } \\
\text { eter }\end{array}$} & \multirow{2}{*}{$\begin{array}{l}\text { Wall } \\
\text { thick- } \\
\text { ness }\end{array}$} & \multirow[b]{2}{*}{$\begin{array}{l}\text { Mini- } \\
\text { mum }\end{array}$} & \multirow[b]{2}{*}{$\begin{array}{l}\text { Maxi- } \\
\text { mum }\end{array}$} & \multirow[b]{2}{*}{$\begin{array}{l}\text { Yield } \\
\text { point }\end{array}$} & \multirow{2}{*}{$\begin{array}{c}\text { Ulti- } \\
\text { mate } \\
\text { strength }\end{array}$} & \multicolumn{2}{|c|}{ Elongation- } & & \\
\hline & & & & & & & & $\begin{array}{c}\text { In } 8 \\
\text { inches }\end{array}$ & $\begin{array}{c}\text { In } 2 \\
\text { inches }\end{array}$ & & \\
\hline & $\begin{array}{l}\mathrm{A} \\
\mathrm{B} \\
\mathrm{C} \\
\mathrm{A} \\
\mathrm{B}\end{array}$ & $\begin{array}{r}\text { Inch } \\
5 / 8 \\
5 / 8 \\
5 / 8 \\
5 / 8 \\
5 / 8\end{array}$ & $\begin{array}{l}\text { Inch } \\
0.028 \\
.028 \\
.028 \\
.032 \\
.032\end{array}$ & $\begin{array}{l}\text { Inch } \\
0.027 \\
.028 \\
.029 \\
.030 \\
.030\end{array}$ & $\begin{array}{l}\text { Inch } \\
0.028 \\
.030 \\
.030 \\
.031 \\
.031\end{array}$ & $\begin{array}{c}\text { Lbs./in. }{ }^{2} \\
39,800 \\
49,000 \\
36,600 \\
53,050 \\
55,400\end{array}$ & \begin{tabular}{|c} 
Lbs./in. ${ }^{2}$ \\
52,200 \\
57,100 \\
52,700 \\
58,450 \\
57,700
\end{tabular} & $\begin{array}{c}\text { Per cent } \\
25.0 \\
16.7 \\
30.0 \\
9.6 \\
6.2\end{array}$ & $\begin{array}{c}\text { Per cent } \\
39.8 \\
32.0 \\
42.5 \\
19.7 \\
15.0\end{array}$ & $\begin{array}{l}66.6 \\
71.2\end{array}$ & in. ${ }^{2}$ \\
\hline & $\begin{array}{l}\text { C } \\
\text { A } \\
\text { B } \\
\text { C } \\
\text { A }\end{array}$ & $\begin{array}{l}5 / 8 \\
5 / 8 \\
5 / 8 \\
5 / 8 \\
5 / 8\end{array}$ & $\begin{array}{l}.032 \\
.035 \\
.035 \\
.035 \\
.049\end{array}$ & $\begin{array}{l}.030 \\
.034 \\
.034 \\
.035 \\
.045\end{array}$ & $\begin{array}{l}.031 \\
.036 \\
.035 \\
.036 \\
.047\end{array}$ & $\begin{array}{l}35,150 \\
46,700 \\
53,000 \\
33,100 \\
56,650\end{array}$ & $\begin{array}{l}48,950 \\
52,050 \\
56,200 \\
49,400 \\
61,000\end{array}$ & $\begin{array}{r}27.1 \\
9.5 \\
5.9 \\
27.7 \\
9.4\end{array}$ & $\begin{array}{l}42.0 \\
24.2 \\
17.0 \\
40.7 \\
22.5\end{array}$ & $\begin{array}{l}59.0 \\
65.3 \\
72.8 \\
59.2 \\
78.6\end{array}$ & \\
\hline 41. & $\begin{array}{l}\mathrm{B} \\
\mathrm{C} \\
\mathrm{A} \\
\mathrm{B} \\
\mathrm{C}\end{array}$ & $\begin{array}{l}5 / 8 \\
5 / 8 \\
7 / 8 \\
7 / 8 \\
7 / 8\end{array}$ & $\begin{array}{l}.049 \\
.049 \\
.035 \\
.035 \\
.035\end{array}$ & $\begin{array}{l}.048 \\
.047 \\
.035 \\
.035 \\
.036\end{array}$ & $\begin{array}{l}.050 \\
.049 \\
.038 \\
.038 \\
.039\end{array}$ & $\begin{array}{l}58,000 \\
39,550 \\
57,050 \\
63,200 \\
37,950\end{array}$ & $\begin{array}{l}62,100 \\
50,400 \\
62,200 \\
66,850 \\
54,000\end{array}$ & $\begin{array}{r}7.5 \\
25.9 \\
10.0 \\
7.8 \\
32.0\end{array}$ & $\begin{array}{l}19.0 \\
38.5 \\
25.0 \\
21.0 \\
48.0\end{array}$ & $\begin{array}{l}78.5 \\
55.2 \\
71.0 \\
71.2 \\
59.0\end{array}$ & \\
\hline $37 \ldots$ & $\begin{array}{l}\mathrm{A} \\
\mathrm{B} \\
\mathrm{C} \\
\mathrm{A} \\
\mathrm{B}\end{array}$ & $\begin{array}{l}7 / 8 \\
7 / 8 \\
7 / 8 \\
7 / 8 \\
7 / 8\end{array}$ & $\begin{array}{l}.042 \\
.042 \\
.042 \\
.049 \\
.049\end{array}$ & $\begin{array}{l}.041 \\
.041 \\
.039 \\
.051 \\
.049\end{array}$ & $\begin{array}{l}.043 \\
.043 \\
.041 \\
.054 \\
.050\end{array}$ & $\begin{array}{l}47,750 \\
56,850 \\
35,200 \\
49,200 \\
51,400\end{array}$ & $\begin{array}{l}51,100 \\
58,000 \\
49,650 \\
53,400 \\
55,150\end{array}$ & $\begin{array}{r}11.8 \\
7.3 \\
33.7 \\
12.2 \\
9.7\end{array}$ & $\begin{array}{l}31.5 \\
22.2 \\
48.7 \\
32.5 \\
26.5\end{array}$ & $\begin{array}{l}65.6 \\
79.4 \\
50.2 \\
65.8 \\
75.1\end{array}$ & \\
\hline $\begin{array}{l}39 \\
34 \ldots \\
35 \\
36 \ldots \\
43 \ldots \\
4\end{array}$ & $\begin{array}{l}\text { C } \\
\text { A } \\
\text { B } \\
\text { C } \\
\text { D }\end{array}$ & $\begin{array}{l}7 / 8 \\
1 \\
1 \\
1\end{array}$ & $\begin{array}{l}.049 \\
.028 \\
.028 \\
.028 \\
.028\end{array}$ & $\begin{array}{l}.052 \\
.027 \\
.028 \\
.027 \\
.030\end{array}$ & $\begin{array}{l}.054 \\
.028 \\
.029 \\
.029 \\
.030\end{array}$ & $\begin{array}{l}34,500 \\
47,150 \\
51,050 \\
38,350 \\
53,650\end{array}$ & $\begin{array}{l}49,750 \\
55,600 \\
57,150 \\
56,750 \\
58,250\end{array}$ & $\begin{array}{r}31.9 \\
15.0 \\
8.6 \\
33.0 \\
8.5\end{array}$ & $\begin{array}{l}47.5 \\
27.5 \\
21.0 \\
44.0 \\
20.5\end{array}$ & $\begin{array}{l}57.1 \\
59.2 \\
64.5 \\
51.8 \\
64.0\end{array}$ & $\begin{array}{l}56,400 \\
56,450 \\
42,200 \\
55,750\end{array}$ \\
\hline $\begin{array}{l}63 \\
64 \\
65 \\
97 \\
98\end{array}$ & $\begin{array}{l}\mathrm{A} \\
\mathrm{B} \\
\mathrm{C} \\
\mathrm{A} \\
\mathrm{B}\end{array}$ & $\begin{array}{l}1 \\
1 \\
1 \\
1 \\
1\end{array}$ & $\begin{array}{l}.035 \\
.035 \\
.035 \\
.035 \\
.035\end{array}$ & $\begin{array}{l}.033 \\
.034 \\
.035 \\
.031 \\
.031\end{array}$ & $\begin{array}{l}.035 \\
.035 \\
.036 \\
.032 \\
.033\end{array}$ & $\begin{array}{l}43,300 \\
48,800 \\
35,600 \\
54,850 \\
61,450\end{array}$ & $\begin{array}{l}51,100 \\
55,000 \\
48,800 \\
57,450 \\
62,200\end{array}$ & $\begin{array}{r}19.2 \\
8.5 \\
30.7 \\
9.5 \\
6.2\end{array}$ & $\begin{array}{l}27.0 \\
18.5 \\
44.0 \\
26.0 \\
15.5\end{array}$ & $\begin{array}{l}60.8 \\
55.4 \\
41.5 \\
67.6 \\
75.8\end{array}$ & $\begin{array}{l}52,400 \\
55,650 \\
43,500 \\
56,250 \\
65,800\end{array}$ \\
\hline
\end{tabular}


TABLE 2.-Results from tensile, hardness, and axial crushing tests-Continued

\begin{tabular}{|c|c|c|c|c|c|c|c|c|c|c|c|}
\hline \multirow{3}{*}{ Tube No. } & \multirow{3}{*}{$\begin{array}{l}\text { Type } \\
\text { of } \\
\text { treat- } \\
\text { ment }\end{array}$} & \multicolumn{2}{|c|}{ Nominal size } & \multicolumn{2}{|c|}{ Wall thickness } & \multicolumn{4}{|c|}{ Tensile test of full section } & \multirow{3}{*}{$\begin{array}{c}\text { Rock- } \\
\text { well } \\
\text { num- } \\
\text { ber, } \\
1 / 16- \\
\text { inch } \\
\text { ball, } \\
100-k g \\
\text { load }\end{array}$} & \multirow{3}{*}{$\begin{array}{c}\text { Axial } \\
\text { crushing } \\
\text { test } \\
\text { (ulti- } \\
\text { mato } \\
\text { strength) }\end{array}$} \\
\hline & & \multirow{2}{*}{$\begin{array}{c}\text { Out- } \\
\text { side } \\
\text { diam- } \\
\text { eter }\end{array}$} & \multirow{2}{*}{$\begin{array}{c}\text { Wall } \\
\text { thick- } \\
\text { ness }\end{array}$} & \multirow[b]{2}{*}{$\begin{array}{l}\text { Mini- } \\
\text { mum }\end{array}$} & \multirow[b]{2}{*}{$\begin{array}{l}\text { Maxi- } \\
\text { mum }\end{array}$} & \multirow[b]{2}{*}{$\begin{array}{l}\text { Yield } \\
\text { point }\end{array}$} & \multirow{2}{*}{$\begin{array}{c}\text { Ulti- } \\
\text { mate } \\
\text { strength }\end{array}$} & \multicolumn{2}{|c|}{ Elongation- } & & \\
\hline & & & & & & & & $\begin{array}{l}\text { In } 8 \\
\text { inches }\end{array}$ & $\begin{array}{c}\text { In } 2 \\
\text { inches }\end{array}$ & & \\
\hline & $\begin{array}{l}\mathrm{E} \\
\mathrm{B} \\
\mathrm{C} \\
\mathrm{D} \\
\mathrm{A}\end{array}$ & $\begin{array}{c}\text { Inches } \\
1 \\
1 \\
1 \\
1 \\
1\end{array}$ & $\begin{array}{l}\text { Inch } \\
0.035 \\
.035 \\
.035 \\
.035 \\
.049\end{array}$ & $\begin{array}{l}\text { Inch } \\
0.034 \\
.034 \\
.035 \\
.035 \\
.048\end{array}$ & $\begin{array}{l}\text { Inch } \\
0.034 \\
.035 \\
.037 \\
.036 \\
.049\end{array}$ & $\begin{array}{c}\text { Lbs./in. }{ }^{2} \\
48,950 \\
54,300 \\
41,100 \\
48,050 \\
49,100\end{array}$ & $\begin{array}{c}\text { Lbs./in. }{ }^{2} \\
54,800 \\
58,050 \\
51,150 \\
52,400 \\
55,250\end{array}$ & \begin{tabular}{|r} 
Per cent \\
13.1 \\
8.7 \\
31.3 \\
15.6 \\
12.5
\end{tabular} & $\mid \begin{array}{c}\text { Per cent } \\
33.0 \\
25.5 \\
49.0 \\
33.0 \\
30.0\end{array}$ & $\begin{array}{l}66.0 \\
71.7 \\
56.0 \\
59.2 \\
66.4\end{array}$ & $\begin{array}{r}\text { Lbs./in. }{ }^{2} \\
55,700 \\
58,300 \\
47,100 \\
54,450 \\
59,100\end{array}$ \\
\hline $29 \ldots$ & $\begin{array}{l}\mathrm{B} \\
\mathrm{C} \\
\mathrm{D} \\
\mathrm{A} \\
\mathrm{B}\end{array}$ & $\begin{array}{l}1 \\
1 \\
1 \\
1 \\
1\end{array}$ & $\begin{array}{l}.049 \\
.049 \\
.049 \\
.065 \\
.065\end{array}$ & $\begin{array}{l}.049 \\
.049 \\
.049 \\
.064 \\
.064\end{array}$ & $\begin{array}{l}.051 \\
.050 \\
.050 \\
.067 \\
.065\end{array}$ & $\begin{array}{l}56,350 \\
33,950 \\
50,300 \\
50,100 \\
50,150\end{array}$ & $\begin{array}{l}59,600 \\
51,950 \\
56,800 \\
53,600 \\
53,150\end{array}$ & $\begin{array}{r}8.2 \\
25.0 \\
10.6 \\
12.8 \\
10.9\end{array}$ & $\begin{array}{l}22.5 \\
38.5 \\
28.0 \\
32.5 \\
30.0\end{array}$ & $\begin{array}{l}72.7 \\
56.2 \\
74.6 \\
70.4 \\
66.2\end{array}$ & $\begin{array}{l}63,450 \\
53,500 \\
59,600 \\
60,750 \\
60,350\end{array}$ \\
\hline 109 & $\begin{array}{l}\text { C } \\
\text { A } \\
\text { B } \\
\text { D } \\
\text { E }\end{array}$ & $\begin{array}{l}1 \\
1 \\
1 \\
1 \\
1\end{array}$ & $\begin{array}{l}.065 \\
.065 \\
.065 \\
.065 \\
.083\end{array}$ & $\begin{array}{l}.064 \\
.064 \\
.065 \\
.063 \\
.079\end{array}$ & $\begin{array}{l}.066 \\
.065 \\
.066 \\
.064 \\
.081\end{array}$ & $\begin{array}{l}34,900 \\
51,050 \\
61,100 \\
46,700 \\
56,000\end{array}$ & $\begin{array}{l}48,250 \\
55,950 \\
63,100 \\
49,000 \\
61,050\end{array}$ & $\begin{array}{r}33.9 \\
11.2 \\
7.0 \\
14.0 \\
10.5\end{array}$ & $\begin{array}{l}51.5 \\
31.0 \\
20.0 \\
25.0 \\
26.0\end{array}$ & $\begin{array}{l}51.0 \\
71.3 \\
79.3 \\
67.2 \\
75.0\end{array}$ & $\begin{array}{l}54,000 \\
60,450 \\
66,600 \\
54,950 \\
68,550\end{array}$ \\
\hline $\begin{array}{l}74 . \\
75\end{array}$ & $\stackrel{\mathrm{B}}{\mathrm{C}}$ & $\begin{array}{l}1 \\
1\end{array}$ & $\begin{array}{l}.083 \\
.083\end{array}$ & $\begin{array}{l}.081 \\
.080\end{array}$ & $\begin{array}{l}.083 \\
.081\end{array}$ & $\begin{array}{l}49,550 \\
37,150\end{array}$ & $\begin{array}{l}59,450 \\
51,550\end{array}$ & $\begin{array}{l}15.2 \\
29.7\end{array}$ & $\begin{array}{l}33.0 \\
48.5\end{array}$ & $\begin{array}{l}77.2 \\
58.2\end{array}$ & $\begin{array}{l}170,350 \\
162,450\end{array}$ \\
\hline $\begin{array}{l}25 \\
26 \\
27-.-\end{array}$ & $\begin{array}{l}\mathrm{A} \\
\mathrm{B} \\
\mathrm{C}\end{array}$ & $\begin{array}{l}11 / 4 \\
11 / 4 \\
11 / 4\end{array}$ & $\begin{array}{l}.049 \\
.049 \\
.049\end{array}$ & $\begin{array}{l}.047 \\
.047 \\
.047\end{array}$ & $\begin{array}{l}.049 \\
.049 \\
.049\end{array}$ & $\begin{array}{l}50,200 \\
53,750 \\
39,600\end{array}$ & $\begin{array}{l}54,250 \\
56,850 \\
52,600\end{array}$ & $\begin{array}{r}14.2 \\
9.7 \\
31.9\end{array}$ & $\begin{array}{l}36.0 \\
27.5 \\
54.0\end{array}$ & $\begin{array}{l}71.9 \\
77.6 \\
56.6\end{array}$ & $\begin{array}{l}55,750 \\
59,350 \\
47,200\end{array}$ \\
\hline $\begin{array}{l}3 \ldots \\
13 \ldots \\
20 \ldots\end{array}$ & $\begin{array}{l}\mathrm{A} \\
\mathrm{B} \\
\mathrm{C} \\
\mathrm{A} \\
\mathrm{B}\end{array}$ & $\begin{array}{l}11 / 2 \\
11 / 2 \\
11 / 2 \\
11 / 2 \\
11 / 2\end{array}$ & $\begin{array}{l}.035 \\
.035 \\
.035 \\
.065 \\
.065\end{array}$ & $\begin{array}{l}.034 \\
.034 \\
.034 \\
.063 \\
.064\end{array}$ & $\begin{array}{l}.035 \\
.035 \\
.035 \\
.064 \\
.065\end{array}$ & $\begin{array}{l}42,950 \\
48,050 \\
37,400 \\
43,000 \\
47,750\end{array}$ & $\begin{array}{l}48,500 \\
50,350 \\
53,350 \\
49,350 \\
50,450\end{array}$ & $\begin{array}{l}25.5 \\
17.3 \\
27.6 \\
23.6 \\
21.5\end{array}$ & $\begin{array}{l}43.0 \\
31.5 \\
45.8 \\
49.5 \\
44.0\end{array}$ & $\begin{array}{l}63.9 \\
68.2 \\
64.9 \\
63.1 \\
73.0\end{array}$ & $\begin{array}{l}46,900 \\
52,100 \\
39,700 \\
52,400 \\
52,550\end{array}$ \\
\hline $\begin{array}{l}21 . . . \\
84-. . \\
10-.- \\
11 . . . \\
11 a_{-.}\end{array}$ & $\begin{array}{l}\mathrm{C} \\
\mathrm{B} \\
\mathrm{A} \\
\mathrm{B} \\
\mathrm{B}\end{array}$ & $\begin{array}{l}11 / 2 \\
13 / 4 \\
2 \\
2 \\
2\end{array}$ & $\begin{array}{l}.065 \\
.120 \\
.035 \\
.035 \\
.035\end{array}$ & $\begin{array}{l}.065 \\
.123 \\
.035 \\
.035 \\
.036\end{array}$ & $\begin{array}{l}.066 \\
.124 \\
.036 \\
.035 \\
.037\end{array}$ & $\begin{array}{l}35,650 \\
55,350 \\
48,350 \\
52,800 \\
54,050\end{array}$ & $\begin{array}{l}52,400 \\
58,650 \\
54,050 \\
54,850 \\
58,550\end{array}$ & $\begin{array}{l}37.2 \\
13.8 \\
19.4 \\
12.6 \\
13.4\end{array}$ & $\begin{array}{l}59.5 \\
38.5 \\
42.0 \\
29.7 \\
32.5\end{array}$ & $\begin{array}{l}46.1 \\
78.8 \\
66.8 \\
67.5 \\
72.2\end{array}$ & $\begin{array}{r}48,200 \\
164,800 \\
48,150 \\
50,950 \\
53,050\end{array}$ \\
\hline $\begin{array}{l}12 \\
12 \mathrm{a} \\
69 \\
47 \\
91\end{array}$ & $\begin{array}{l}\mathrm{C} \\
\mathrm{C} \\
\mathrm{E} \\
\mathrm{D} \\
\mathrm{A}\end{array}$ & $\begin{array}{l}2 \\
2 \\
2 \\
2 \\
2\end{array}$ & $\begin{array}{l}.035 \\
.035 \\
.035 \\
.035 \\
.049\end{array}$ & $\begin{array}{l}.035 \\
.034 \\
.033 \\
.034 \\
.050\end{array}$ & $\begin{array}{l}.037 \\
.036 \\
.034 \\
.036 \\
.052\end{array}$ & $\begin{array}{l}36,700 \\
36,650 \\
34,150 \\
52,450 \\
44,400\end{array}$ & $\begin{array}{l}52,900 \\
50,150 \\
44,800 \\
56,300 \\
50,150\end{array}$ & $\begin{array}{l}34.8 \\
33.5 \\
32.1 \\
11.9 \\
18.4\end{array}$ & $\begin{array}{l}57.0 \\
57.0 \\
53.0 \\
31.0 \\
45.5\end{array}$ & $\begin{array}{l}52.9 \\
56.3 \\
46.4 \\
76.4 \\
66.9\end{array}$ & $\begin{array}{l}39,750 \\
40,400 \\
35,650 \\
49,650 \\
47,500\end{array}$ \\
\hline $\begin{array}{l}90-- \\
48=- \\
71-- \\
70-- \\
72=\end{array}$ & $\begin{array}{l}\mathrm{B} \\
\mathrm{D} \\
\mathrm{E} \\
\mathrm{B} \\
\mathrm{C}\end{array}$ & $\begin{array}{l}2 \\
2 \\
2 \\
2 \\
2\end{array}$ & $\begin{array}{l}.049 \\
.049 \\
.065 \\
.065 \\
.065\end{array}$ & $\begin{array}{l}.051 \\
.050 \\
.062 \\
.062 \\
.061\end{array}$ & $\begin{array}{l}.052 \\
.050 \\
.063 \\
.063 \\
.064\end{array}$ & $\begin{array}{l}49,100 \\
54,850 \\
46,300 \\
47,900 \\
35,850\end{array}$ & $\begin{array}{l}52,700 \\
59,450 \\
51,700 \\
53,700 \\
48,950\end{array}$ & $\begin{array}{l}13.0 \\
12.5 \\
23.1 \\
16.1 \\
33.2\end{array}$ & $\begin{array}{l}30.5 \\
33.0 \\
46.0 \\
40.5 \\
53.5\end{array}$ & $\begin{array}{l}69.9 \\
72.5 \\
69.8 \\
70.0 \\
57.0\end{array}$ & $\begin{array}{l}51,300 \\
55,750 \\
52,150 \\
52,500 \\
41,350\end{array}$ \\
\hline $\begin{array}{l}51 \ldots \\
49 . \ldots \\
107 . . \\
50 \ldots \\
106 .-\end{array}$ & $\begin{array}{l}\mathrm{D} \\
\mathrm{H} \\
\mathrm{H} \\
\mathrm{D} \\
\mathrm{D}\end{array}$ & $\begin{array}{l}2 \\
2 \\
2 \\
2 \\
2\end{array}$ & $\begin{array}{l}.065 \\
.065 \\
.065 \\
.083 \\
.083\end{array}$ & $\begin{array}{l}.062 \\
.066 \\
.065 \\
.080 \\
.081\end{array}$ & $\begin{array}{l}.063 \\
.067 \\
.066 \\
.081 \\
.082\end{array}$ & $\begin{array}{l}49,950 \\
67,200 \\
74,350 \\
45,700 \\
57,150\end{array}$ & $\begin{array}{l}55,700 \\
68,650 \\
78,250 \\
50,050 \\
58,850\end{array}$ & $\begin{array}{r}13.1 \\
3.1 \\
2.5 \\
18.8 \\
12.4\end{array}$ & $\begin{array}{r}37.0 \\
9.5 \\
7.0 \\
48.0 \\
38.0\end{array}$ & $\begin{array}{l}69.5 \\
83.9 \\
89.6 \\
64.2 \\
79.6\end{array}$ & $\begin{array}{r}55,050 \\
69,700 \\
279,050 \\
351,800 \\
60,250\end{array}$ \\
\hline $\begin{array}{l}22 \ldots \ldots \\
23 \ldots \ldots \\
24 \\
58\end{array}$ & $\begin{array}{l}\mathrm{A} \\
\mathrm{B} \\
\mathrm{C} \\
\mathrm{D}\end{array}$ & $\begin{array}{l}21 / 4 \\
21 / 4 \\
21 / 4 \\
21 / 2\end{array}$ & $\begin{array}{l}.049 \\
.049 \\
.049 \\
.035\end{array}$ & $\begin{array}{l}.048 \\
.047 \\
.049 \\
.034\end{array}$ & $\begin{array}{l}.049 \\
.049 \\
.050 \\
.035\end{array}$ & $\begin{array}{l}45,600 \\
47,250 \\
32,100 \\
54,850\end{array}$ & $\begin{array}{l}47,300 \\
48,600 \\
47,550 \\
56,850\end{array}$ & $\begin{array}{l}30.0 \\
27.2 \\
31.2 \\
12.2\end{array}$ & $\begin{array}{l}52.7 \\
44.5 \\
60.5 \\
35.0\end{array}$ & $\begin{array}{l}57.8 \\
59.5 \\
47.2 \\
74.3\end{array}$ & $\begin{array}{l}44,250 \\
47,100 \\
39,800 \\
51,450\end{array}$ \\
\hline $\begin{array}{l}57 \ldots \ldots \\
104 \\
56 \\
59\end{array}$ & $\begin{array}{l}\mathrm{D} \\
\mathrm{H} \\
\mathrm{D} \\
\mathrm{D}\end{array}$ & $\begin{array}{l}21 / 2 \\
21 / 2 \\
21 / 2 \\
21 / 2\end{array}$ & $\begin{array}{l}.065 \\
.065 \\
.083 \\
.083\end{array}$ & $\begin{array}{l}.060 \\
.060 \\
.080 \\
.080\end{array}$ & $\begin{array}{l}.062 \\
.062 \\
.081 \\
.082\end{array}$ & $\begin{array}{l}55,200 \\
70,850 \\
57,700 \\
53,100\end{array}$ & $\begin{array}{l}58,450 \\
75,850 \\
62,800 \\
58,800\end{array}$ & $\begin{array}{r}13.4 \\
2.5 \\
14.9 \\
22.6\end{array}$ & $\begin{array}{r}40.0 \\
7.0 \\
37.0 \\
44.5\end{array}$ & $\begin{array}{l}79.0 \\
87.1 \\
85.0 \\
82.2\end{array}$ & $\begin{array}{r}55,100 \\
273,100 \\
62,050 \\
56,500\end{array}$ \\
\hline $\begin{array}{l}105 \ldots \\
85 \ldots \\
86 \ldots \\
62 \ldots\end{array}$ & $\begin{array}{l}D \\
B \\
D \\
D\end{array}$ & $\begin{array}{l}21 / 2 \\
21 / 2 \\
2^{3 / 4} \\
3\end{array}$ & $\begin{array}{l}.083 \\
.095 \\
.083 \\
.042\end{array}$ & $\begin{array}{l}.079 \\
.097 \\
.083 \\
.041\end{array}$ & $\begin{array}{l}.081 \\
.097 \\
.085 \\
.042\end{array}$ & $\begin{array}{l}57,500 \\
63,500 \\
60,850 \\
47,850\end{array}$ & $\begin{array}{l}64,150 \\
72,450 \\
66,300 \\
55,050\end{array}$ & $\begin{array}{l}13.1 \\
15.7 \\
15.6 \\
17.9\end{array}$ & $\begin{array}{l}19.0 \\
42.0 \\
34.5 \\
35.5\end{array}$ & $\begin{array}{l}81.6 \\
85.9 \\
63.5 \\
78.0\end{array}$ & $\begin{array}{l}61,600 \\
68,400 \\
61,700 \\
43,100\end{array}$ \\
\hline $\begin{array}{l}61 \\
102 \\
60 \\
103\end{array}$ & $\begin{array}{l}D \\
D \\
D \\
D\end{array}$ & $\begin{array}{l}3 \\
3 \\
3 \\
3\end{array}$ & $\begin{array}{l}.065 \\
.065 \\
.083 \\
.083\end{array}$ & $\begin{array}{l}.061 \\
.063 \\
.079 \\
.080\end{array}$ & $\begin{array}{l}.062 \\
.064 \\
.081 \\
.082\end{array}$ & $\begin{array}{l}45,050 \\
52,350 \\
51,900 \\
48,950\end{array}$ & $\begin{array}{l}54,550 \\
57,600 \\
59,900 \\
56,100\end{array}$ & $\begin{array}{l}21.9 \\
23.5 \\
15.8 \\
19.9\end{array}$ & $\begin{array}{l}46.0 \\
52.0 \\
37.5 \\
45.5\end{array}$ & $\begin{array}{l}74.8 \\
77.2 \\
82.7 \\
77.0\end{array}$ & $\begin{array}{l}47,700 \\
51,100 \\
55,500 \\
51,000\end{array}$ \\
\hline
\end{tabular}




\section{B. S. Journal of Research, RP161}

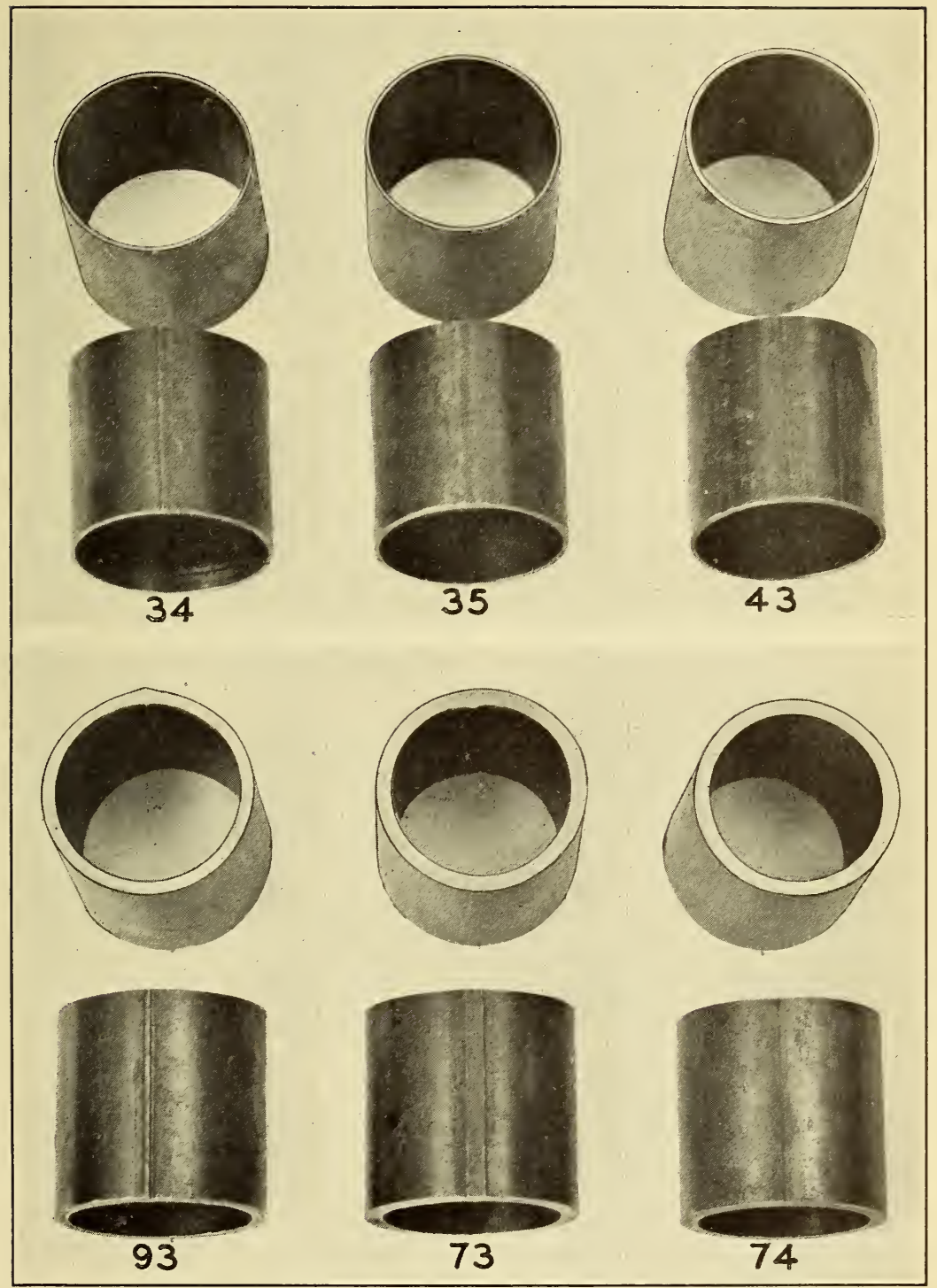

Figure 1.-Cross sections and welds of some 1-inch tubes

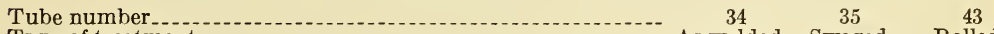
Type of treatment. Rolled.

Tube number

Type of treatment. 


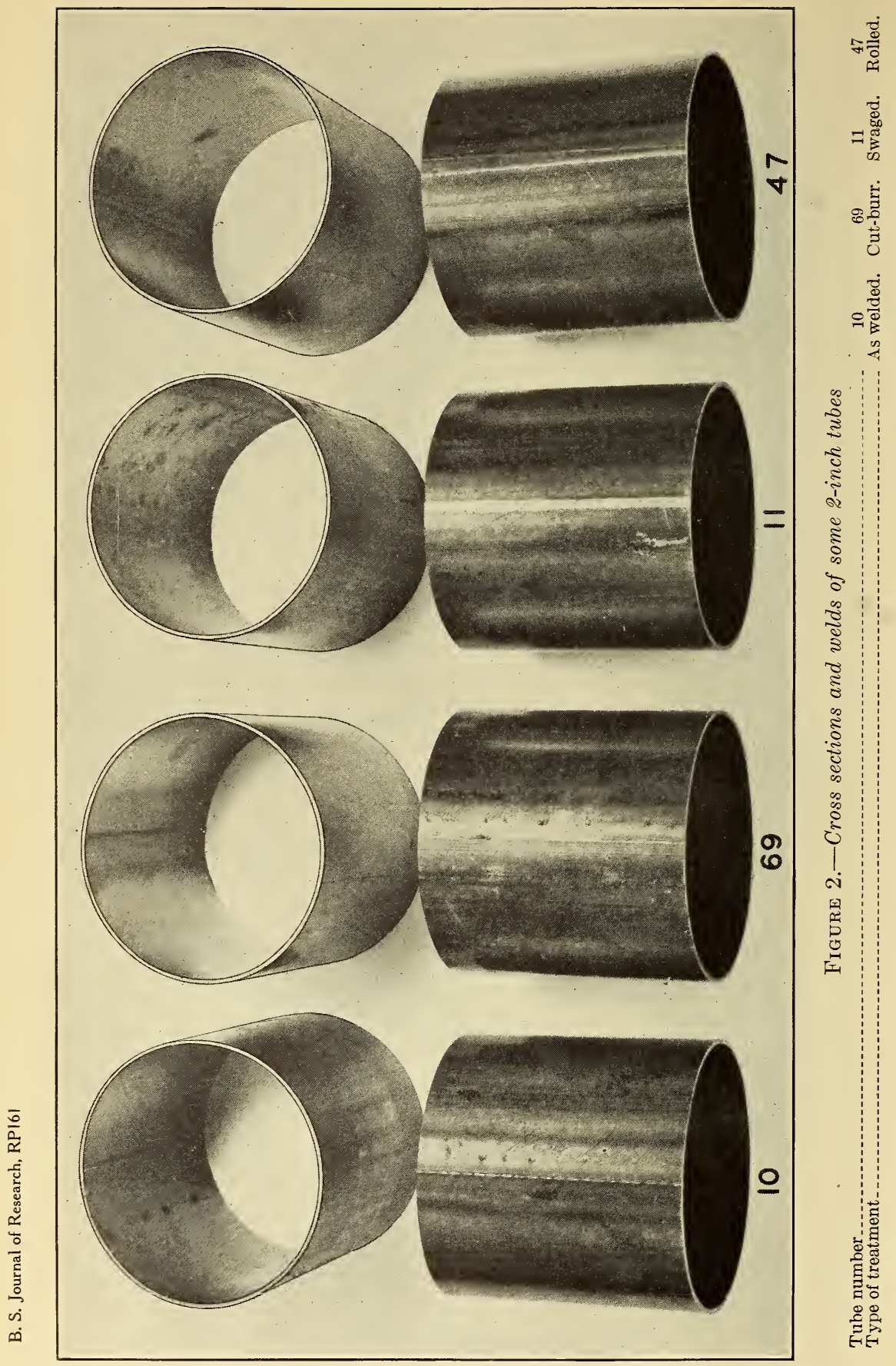


TABLE 2.-Results from tensile, hardness, and axial crushing tests-Continued

\begin{tabular}{|c|c|c|c|}
\hline Symbol & Type of treatment & Symbol & Type of treatment \\
\hline A & $\begin{array}{l}\text { As-welded. } \\
\text { Swaged. } \\
\text { Swaged-annealed. }\end{array}$ & D & $\begin{array}{l}\text { Rolled. } \\
\text { Cut-burr. } \\
\text { Hard-rolled. }\end{array}$ \\
\hline
\end{tabular}

\section{METHOD OF MANUFACTURE}

Strip steel of the required width is passed through a series of rolls to give it the tubular form.

The edges along the longitudinal seam are accurately butted as the blank is propelled under two electrodes which make continuous contact on both sides of the seam. The electrical resistance of the metal brings the abutting edges to the welding temperature. Forces are immediately applied by mechanical fixtures to complete the weld. The tubing is said to be welded at a speed of about 50 feet per minute.

\section{(a) TYPES OF TREATMENT}

Figures 1 and 2 show the typical cross sections and welds of some of the tubes.

(1) As welded.-This tubing is in the condition in which it comes from the welding machine. It has a small burr on the inside and outside at the weld. The diameter is from 0.02 to 0.04 inch greater than the nominal outside diameter.

(2) Cut-burr.-This tubing is similar to the as-welded tubing except that the outside burr has been removed by a planer tool as it leaves the welding machine.

(3) Swaged.-The as-welded tubing is passed through a swaging machine which reduces its outside diameter to the nominal size and removes the burr on both sides. The machine has a pair of dies, each of which has a slightly tapered longitudinal semicylindrical groove. The opposite end of the dies from which the tube enters conforms to the desired outside diameter of the tube. A cylindrical mandrel, of a size corresponding to the desired inside diameter of the tube, is inserted and held stationary at a point between the dies. The dies revolve about the tube and at the same time hammer it to its nominal size while the tube is being pulled through the machine.

The as-welded tubing may also be swaged without the stationary mandrel on the inside, thus forming a tube of uniform thickness and outside diameter, but with a small burr on the inside at the weld.

The variations in thickness of wall and in outside diameter of swaged tubes are small.

(4) Rolled.-The as-welded tubing is passed through a series of rolls arranged in pairs, each roll having a semicircular groove. These rolls reduce the outside diameter to the nominal size and roll down the burr. A mandrel, in which small rolls are mounted and adjusted to conform to the desired inside diameter of the tube, is inserted and held stationary in the tube at a point between the outside rolls. The rolls in the mandrel roll down the inside burr.

The thickness of wall at the weld of the rolled tubes is somewhat greater for a width of 0.10 to 0.20 inch, the increase being from 2 to 20 per cent and averaging 8 per cent. Due to the rolling operation, 
the outside diameter of the tubing is constant, but the inside diameter is least at the weld.

(5) Hard rolled.-The strip steel from which this tubing is made is cold worked to a greater extent than other rolled tubing, which increases its strength.

(6) Annealed.-The ductility of the tubing which has been cold worked in previous operations may be increased by annealing. Annealed tubing is used for parts which are greatly deformed in fabrication.

The only annealed tubes that were included in this investigation were annealed after swaging.

\section{METHODS OF TESTING AND RESULTS}

To determine the difference in tensile strengths at the ends of some of the 15-foot lengths of tube, one tensile specimen was cut

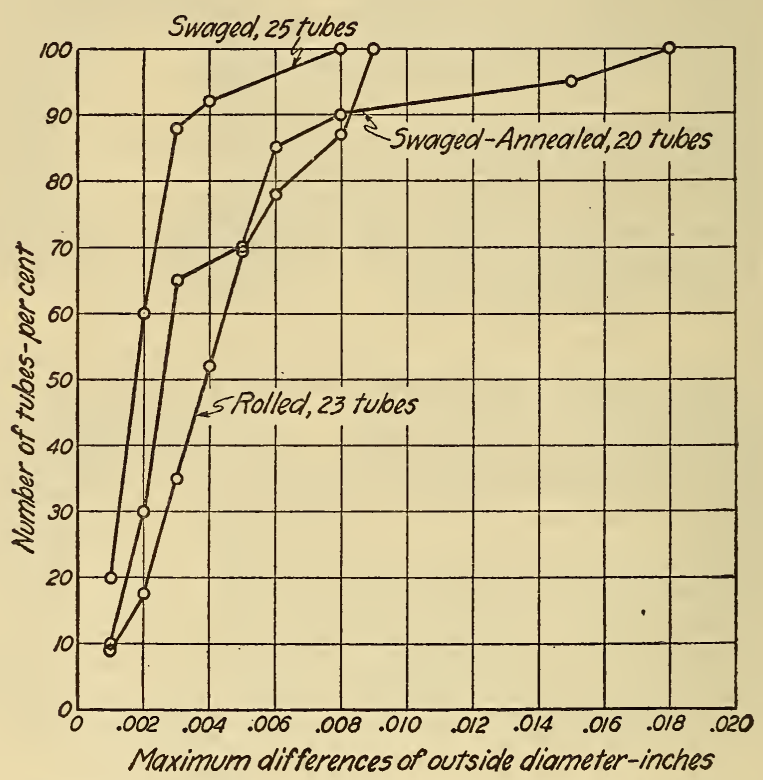

Figure 3.-Maximum differences of outside diameter

To find the number of tubes which did not exceed a given tolerance, say 0.006 inch, find 0.006 on the horizontal scale, then determine where the ordinate cuts the curve for the tube of the desired treatment, say "swaged." Read the number of tubes horizontally on the scale at the left. For this case, 96 per cent of the 25 "swaged" tubes did not exceed the tolerance.

from each end of tubes Nos. 1 to 25, inclusive. The average difference between the tensile strengths of the two specimens was 1.2 per cent and the maximum difference was 2.5 per cent. It was concluded, therefore, that the physical properties did not vary appreciably in the length of the tube. Only one tensile specimen was cut from each of the remaining tubes, which varied in length from 10 to 18 feet, and no sequence for cutting specimens from the remaining length was followed in the various tests. 


\section{DIAMETER AND THICKNESS OF WALL}

The outside diameters of swaged, rolled, and swaged-annealed tubes were measured to the nearest 0.001 inch at four equally spaced diameters around the tube. These measurements were taken at an arbitrarily selected cross section of the tube.

After the tube had been cut into lengths for specimens, the thickness at the ends of the specimens was measured to the nearest 0.001 inch on four elements equally spaced around the tube. One of these measurements was taken on the weld of the swaged and swaged-annealed tubes, but not on the weld of the as-welded, cut-burr, or rolled tubes. The thickness of the wall did not vary longitudinally more than 0.001 inch on any given element of the cylinder.

The maximum differences in outside diameters and wall thicknesses of the four measurements are shown in Figures 3 and 4.

Figure 3 shows the per cent of the 25-swaged, 23 -rolled, and 20 -swaged-annealed tubes having the maximum differences of outside diameters indicated.

Figure 4 shows the per cent of the 91 tubes of all types of treatment having the maximum differences of wall thickness indicated.

\section{TENSILE TEST OF FULL SECTION}

One tensile specimen, 20 inches long, was cut from each length of tubing and then marked with a center punch at each inch along opposite elements of the cylinder for a distance of 10 inches. Mandrels which fitted the inside of the tube were inserted into each end of the specimen. These mandrels were slightly longer than the jaws of the testing machine, and their inner ends were rounded.

The testing machine had a capacity of 100,000 pounds. It was of the universal screw-power type and driven by an electric motor. The ends of the specimen were gripped between the V-shaped grooves of the jaws.

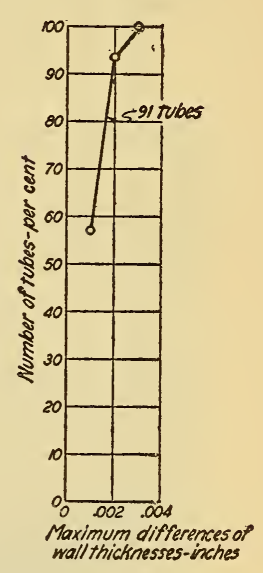

Figure 4.-Maximum differences of wall thickness

To find the number of tubes which did not exceed a given tolerance, say 0.002 inch, find 0.002 on the horizontal scale, then determine where the or dinate cuts the curve representing the tubes of all types of treatment. Read the number of tubes horizontally on the scale at the left. Then 93 per cent of the 91 tubes did not exceed the tolerance.

The yield point was determined by the drop of the beam and checked by dividers set on the specimen on an 8-inch gage length. The speed of the moving head of the machine was 0.11 inch per minute during this part of the test. The speed was then increased to the next higher speed of 0.44 inch per minute, which was maintained until the ultimate load and fracture were reached.

The elongation was determined by fitting the fractured ends together and measuring the distances between original 2 and 8 inch gage marks on each side of the fracture. These marks were selected so as to have the fracture as near the center of this distance as possible.

The yield point, ultimate strength, and elongation for each tube are given in Table 2, and the average of these for the different types of treatment are given in Table 3 . 
The modulus of elasticity and proportional limit were obtained from a few specimens of the different type's of treatment. One-inch tubes were selected because they were available in a wide range of

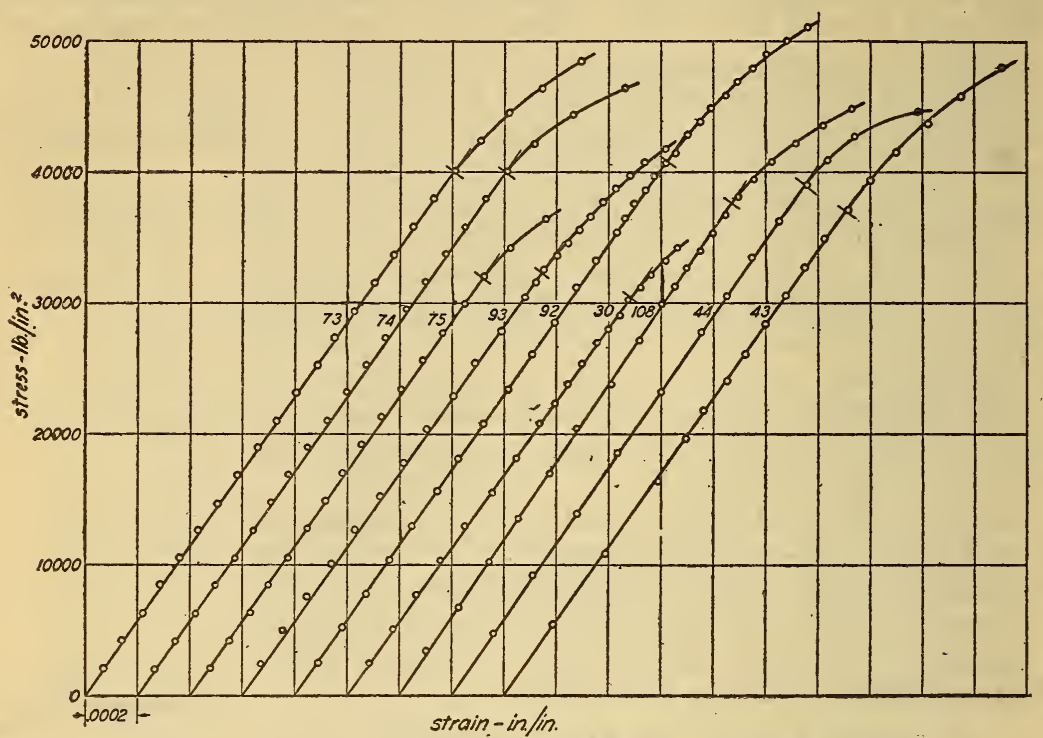

FIgURE 5.-Typical stress-strain curves, tensile test

thicknesses. A Ewing extensometer was used on an 8-inch gage length. The deformation was measured to 0.0002 inch by the smallest division and estimated to 0.00002 inch.

The stress-strain curves for the nine specimens tested are shown in Figure 5 and the numerical results are given in Table 4.

TABLE 3.-Average results of tensile tests of full section and axial crushing test for the different types of treatment

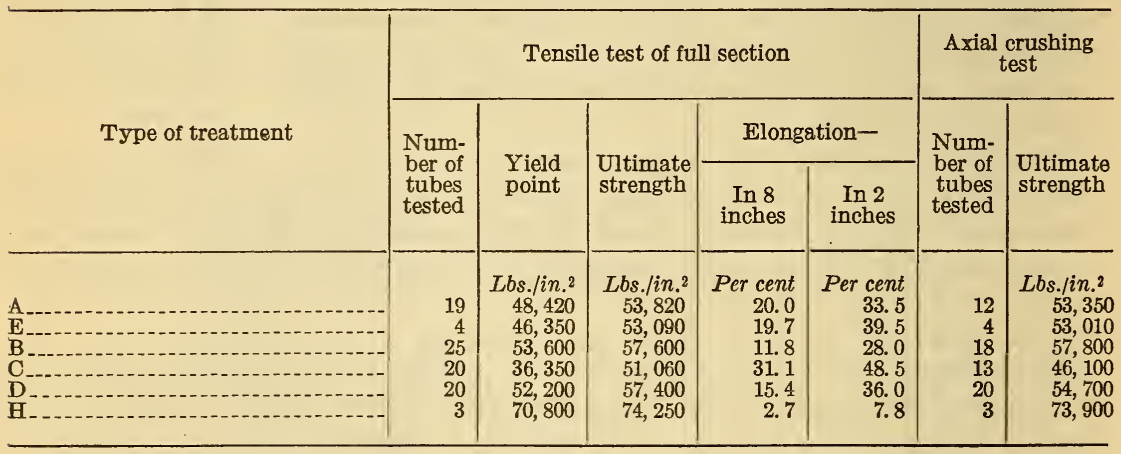

\begin{tabular}{|c|c|c|c|}
\hline Symbol & Type of treatment & Symbol & Type of treatment \\
\hline $\begin{array}{l}\mathrm{A} \\
\mathrm{B} \\
\mathrm{C}\end{array}$ & $\begin{array}{l}\text { As-welded. } \\
\text { Swaged. } \\
\text { Swaged-annealed. }\end{array}$ & $\begin{array}{l}\mathrm{D} \\
\mathrm{E} \\
\mathrm{H}\end{array}$ & $\begin{array}{l}\text { Rolled. } \\
\text { Cut-burr. } \\
\text { Hard-rolled. }\end{array}$ \\
\hline
\end{tabular}




\section{B. S. Journal of Research, RP161}

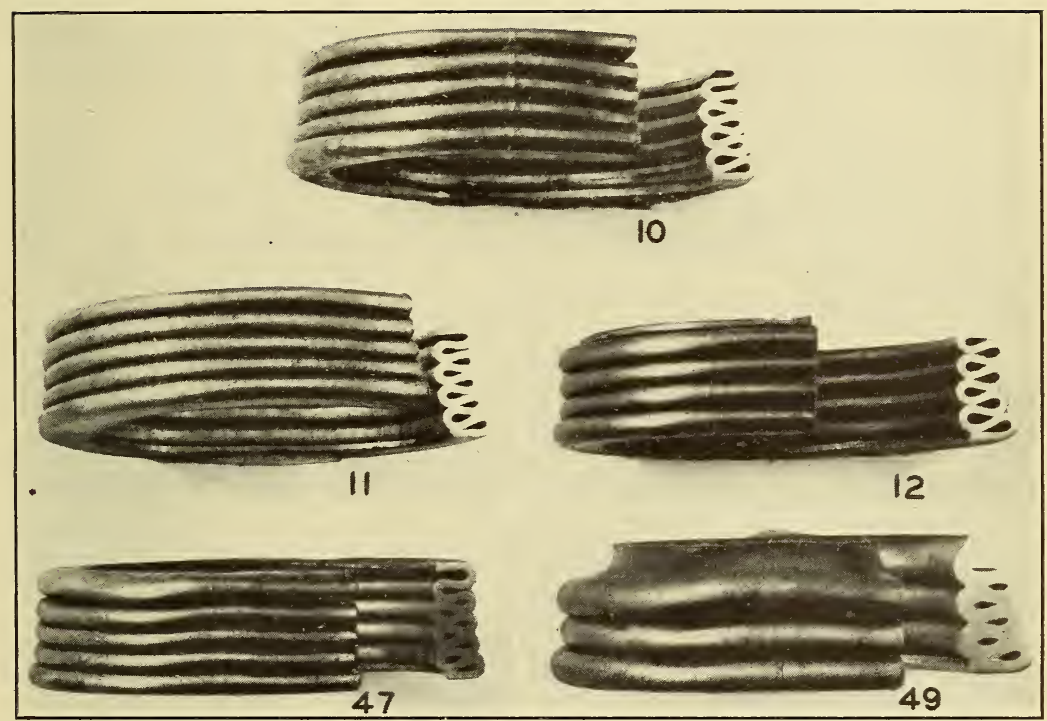

Figure 6.-Typical crush specimens

Type number--.--10-- $10 \quad 11$

Type of treatment.... As welded. Swaged. Swaged-annealed. Rolled. Harded. 
B. S. Journal of Research, RP161

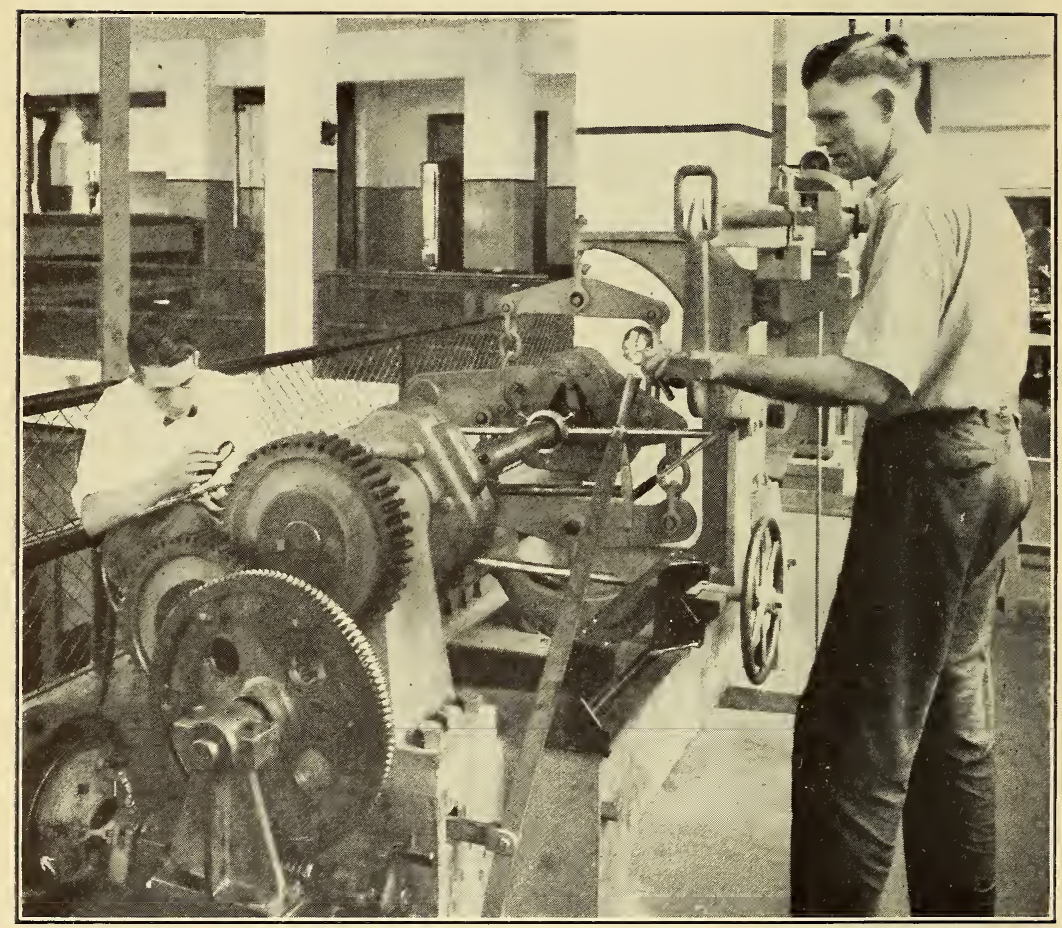

FIgure 7.-Torsion machine with a specimen under test 
TABLE 4.-Results of tensile tests of full section to obtain stress-strain curves

\begin{tabular}{|c|c|c|c|c|c|c|c|c|c|c|c|}
\hline \multirow[b]{2}{*}{ Tube No. } & \multirow{2}{*}{$\begin{array}{l}\text { Type } \\
\text { of } \\
\text { treat- } \\
\text { ment }\end{array}$} & \multicolumn{2}{|c|}{ Nominal size } & \multicolumn{2}{|c|}{ Wall thickness } & \multirow{2}{*}{$\begin{array}{c}\text { Stress at } \\
\text { propor- } \\
\text { tional } \\
\text { limit }\end{array}$} & \multirow[b]{2}{*}{$\begin{array}{l}\text { Yield } \\
\text { point }\end{array}$} & \multirow[b]{2}{*}{$\begin{array}{l}\text { Ultimate } \\
\text { strength }\end{array}$} & \multicolumn{2}{|c|}{ Elongation- } & \multirow{2}{*}{$\begin{array}{l}\text { Modulus } \\
\text { of elas- } \\
\text { ticity }\end{array}$} \\
\hline & & $\begin{array}{l}\text { Out- } \\
\text { side } \\
\text { diam- } \\
\text { eter }\end{array}$ & $\begin{array}{l}\text { Wall } \\
\text { thick- } \\
\text { ness }\end{array}$ & $\begin{array}{l}\text { Mini- } \\
\text { mum }\end{array}$ & $\begin{array}{l}\text { Maxi- } \\
\text { mum }\end{array}$ & & & & In 8 & $\underset{\text { inches }}{\text { In } 2}$ & \\
\hline $\begin{array}{l}43- \\
44- \\
108 \\
30- \\
93- \\
92 \\
73- \\
74- \\
75\end{array}$ & $\begin{array}{l}\mathrm{D} \\
\mathrm{D} \\
\mathrm{D} \\
\mathrm{C} \\
\mathrm{A} \\
\mathrm{B} \\
\mathrm{C} \\
\mathrm{B} \\
\mathrm{C}\end{array}$ & $\begin{array}{r}\text { Inch } \\
1 \\
1 \\
1 \\
1 \\
1 \\
1 \\
1 \\
1 \\
1\end{array}$ & $\begin{array}{l}\text { Inch } \\
0.028 \\
.035 \\
.049 \\
.065 \\
.065 \\
.065 \\
.083 \\
.083 \\
.083\end{array}$ & $\begin{array}{l}\text { Inch } \\
0.030 \\
.035 \\
.049 \\
.064 \\
.064 \\
.065 \\
.079 \\
.081 \\
.080\end{array}$ & $\begin{array}{l}\text { Inch } \\
0.030 \\
.036 \\
.050 \\
.066 \\
.065 \\
.066 \\
.081 \\
.083 \\
.081\end{array}$ & $\begin{array}{c}\text { Lbs./in. }{ }^{2} \\
37,000 \\
39,000 \\
37,600 \\
30,400 \\
32,400 \\
40,800 \\
40,000 \\
40,000 \\
32,000\end{array}$ & $\begin{array}{c}\text { Lbs./in. }{ }^{2} \\
53,650 \\
48,050 \\
50,300 \\
34,900 \\
51,050 \\
61,100 \\
56,000 \\
49,500 \\
37,150\end{array}$ & $\begin{array}{c}\text { Lbs./in. }{ }^{2} \\
58,350 \\
52,400 \\
57,000 \\
47,020 \\
56,250 \\
62,500 \\
61,500 \\
59,000 \\
49,300\end{array}$ & $\begin{array}{r}\text { Per cent } \\
8.4 \\
14.2 \\
10.0 \\
33.2 \\
12.0 \\
6.1 \\
10.6 \\
15.4 \\
29.5\end{array}$ & $\begin{array}{c}P e^{m} \text { cent } \\
17.0 \\
32.5 \\
24.5 \\
53.5 \\
29.5 \\
17.5 \\
25.5 \\
31.5 \\
49.0\end{array}$ & $\begin{array}{c}\text { Lbs./in. }{ }^{2} \\
28,460,000 \\
28,890,000 \\
29,600,000 \\
28,140,000 \\
28,410,000 \\
28,730,000 \\
28,580,000 \\
28,580,000 \\
28,700,000\end{array}$ \\
\hline
\end{tabular}

\begin{tabular}{|l|l||l|l|}
\hline Symbol & Type of treatment & Symbol & Type of treatment \\
\cline { 2 - 4 } & $\begin{array}{l}\text { As-welded. } \\
\text { A }\end{array}$ & $\begin{array}{l}\text { D }-1 .- \\
\text { Swaged. }\end{array}$ & $\begin{array}{l}\text { Rolled. } \\
\text { Cut-burr. } \\
\text { Sward-rolled. }\end{array}$ \\
\hline
\end{tabular}

\section{AXIAL CRUSHING TEST}

This test was made on all tubes of 1 to 3 inches outside diameter, inclusive.

The specimens, $2 \frac{1}{2}$ inches long, were cut from the tube in a lathe, and loaded longitudinally in a testing machine. The moving head of the machine applied its force through a spherical bearing. The speed of the moving head was 0.11 inch per minute, and as the ultimate load was reached the specimen started to crinkle. The speed was then increased to 0.44 inch per minute and the test completed by crushing the whole specimen into folds. The results are given in Table 2.

A few typical specimens are shown in Figure 6. The weld is nearest the observer, and a segment is cut away to show a section of the folded metal.

\section{TORSION TEST}

This test was made on swaged and rolled tubes of 1 to 3 inches outside diameter, inclusive. The total length of each specimen was 43 inches and the gage length was 30 inches. Mandrels which fitted the inside of the tube were inserted into each end of the specimen to prevent the tube from being crushed between the jaws of the torsion machine.

Figure 7 shows the torsion machine with a specimen under test. Figure 8 shows the twist-measuring instrument assembled on a specimen. With specimen $A$ in the torsion machine the $\operatorname{ring} B$, supporting the pointers, and the ring $C$, supporting the arcs, are spaced and held perpendicular to the specimen by pressing them against the end faces of jig $D$ when it is resting on the specimen on its V-shaped ends. The rings are made concentric with the tube by adjusting three radial screws, having square ends, set $120^{\circ}$ apart in 
the ring. Between the square-ended screws are sharp-pointed screws similarly spaced, which are screwed down against the tube so the ring can not turn on the tube. The jig is then removed, and the balanced pointer $E$ set into a semicircular groove at the end of the supporting arm and made secure by thumbscrew $F$. The small glass $G$, with a horizontal hairline, is attached to the end of the balanced pointer by means of a thin flat spring. The spring keeps the glass against the 6 -inch flexible scale $H$, which is held on the aluminum arc by brass clips. The two sides of the instrument are similar.

The distance between the points of the screws in the two rings when spaced on the specimen by jig $D$ is 30 inches. This is the gage length. The distance between the axis of the specimen, when the specimen is concentric with the ring, and the outside face of the flexible scale is 19 inches. The arms extending from the rings and the pointers are 1 -inch and $5 / 8$-inch steel tubes, respectively; both are about 0.028 inch in thickness.

The scales were graduated to 0.01 inch. By using a magnifying glass the readings were made to 0.001 inch. The two scale readings were taken simultaneously for each increment of applied torque until the yield point was reached. The instrument was then dismantled by removing the balanced pointers and loosening the screws in the rings. The torque was increased to obtain the ultimate strength, and the specimen was twisted until it buckled and bent too much to keep the weighing head of the machine in line.

None of the torsion specimens showed any fracture in the weld. Figure 9 shows some of the torsion specimens.

For circular tubes the stress in the extreme fiber at the proportional limit is calculated from the formula

$$
S=\frac{T c}{J}
$$

in which $S$ is the stress, $T$ the torque, $c$ the outside radius of the tube, and $J$ the polar moment of inertia calculated from the formula

$$
J=\frac{3.1416\left(D^{4}-d^{4}\right)}{32}
$$

in which $D$ is the outside diameter and $d$ the inside diameter of the tube. Figure 10 shows values of $\frac{T c}{J}$ plotted against shearing strain at the surface, and the numerical results are given in Table 5 . It may be pointed out that values of $\frac{T c}{J}$ above the proportional limit do not represent stress in the extreme fiber unless the tube is sufficiently thin to justify assuming a uniform distribution of shearing stress across the thickness of the tube. 
B. S. Journal of Research, RP161

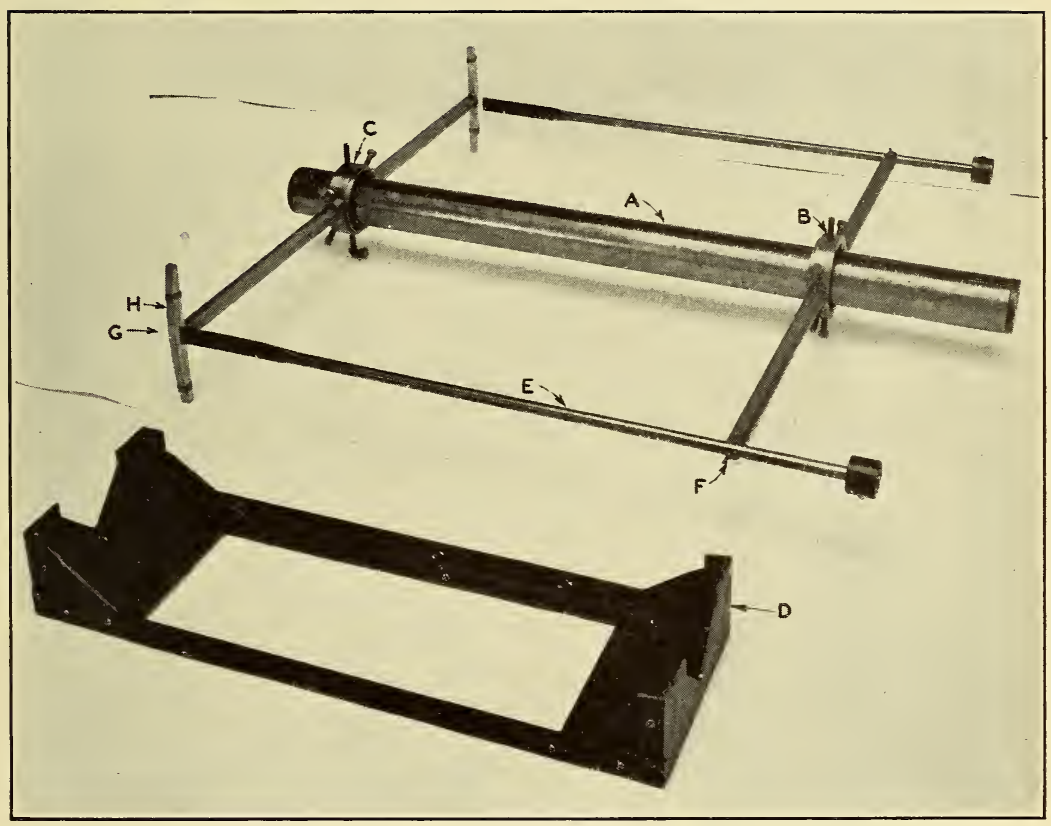

FIGURE 8.-T wist meter assembled on a specimen and spacing jig 
B. S. Journal of Research, RP161

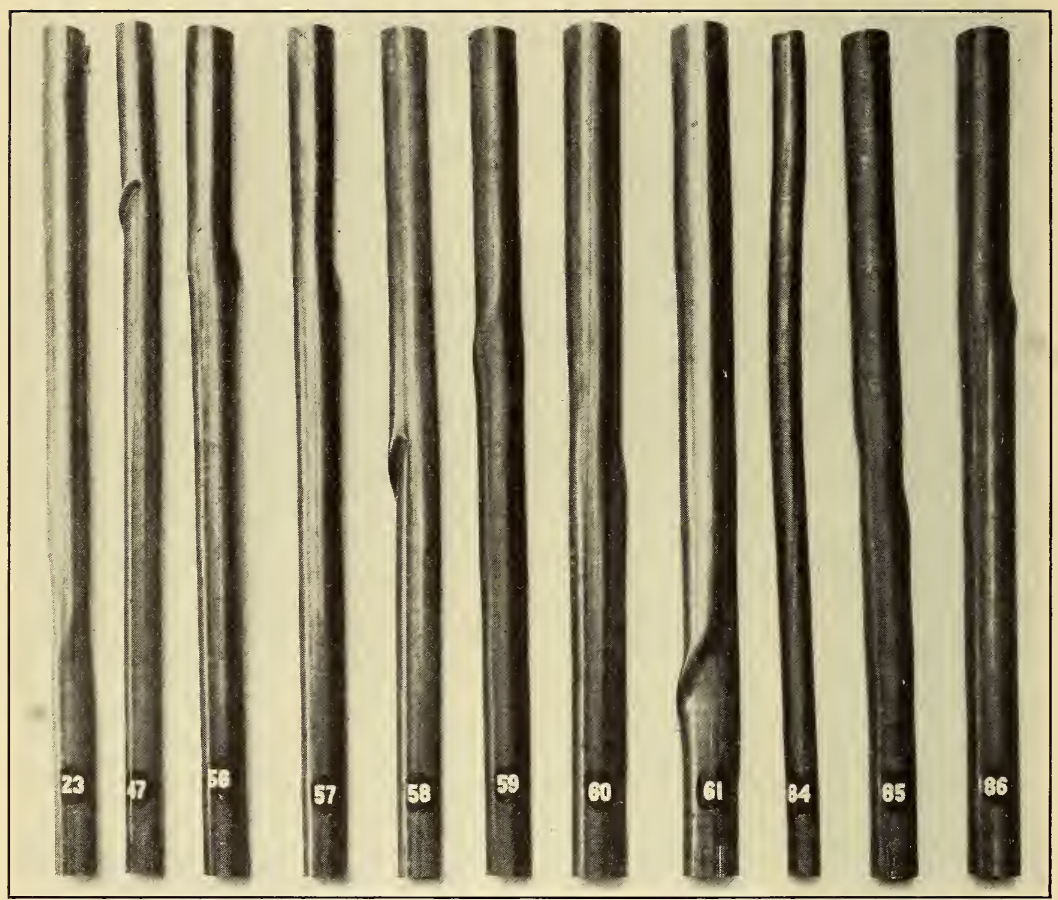

Figure 9.-Typical torsion specimens 


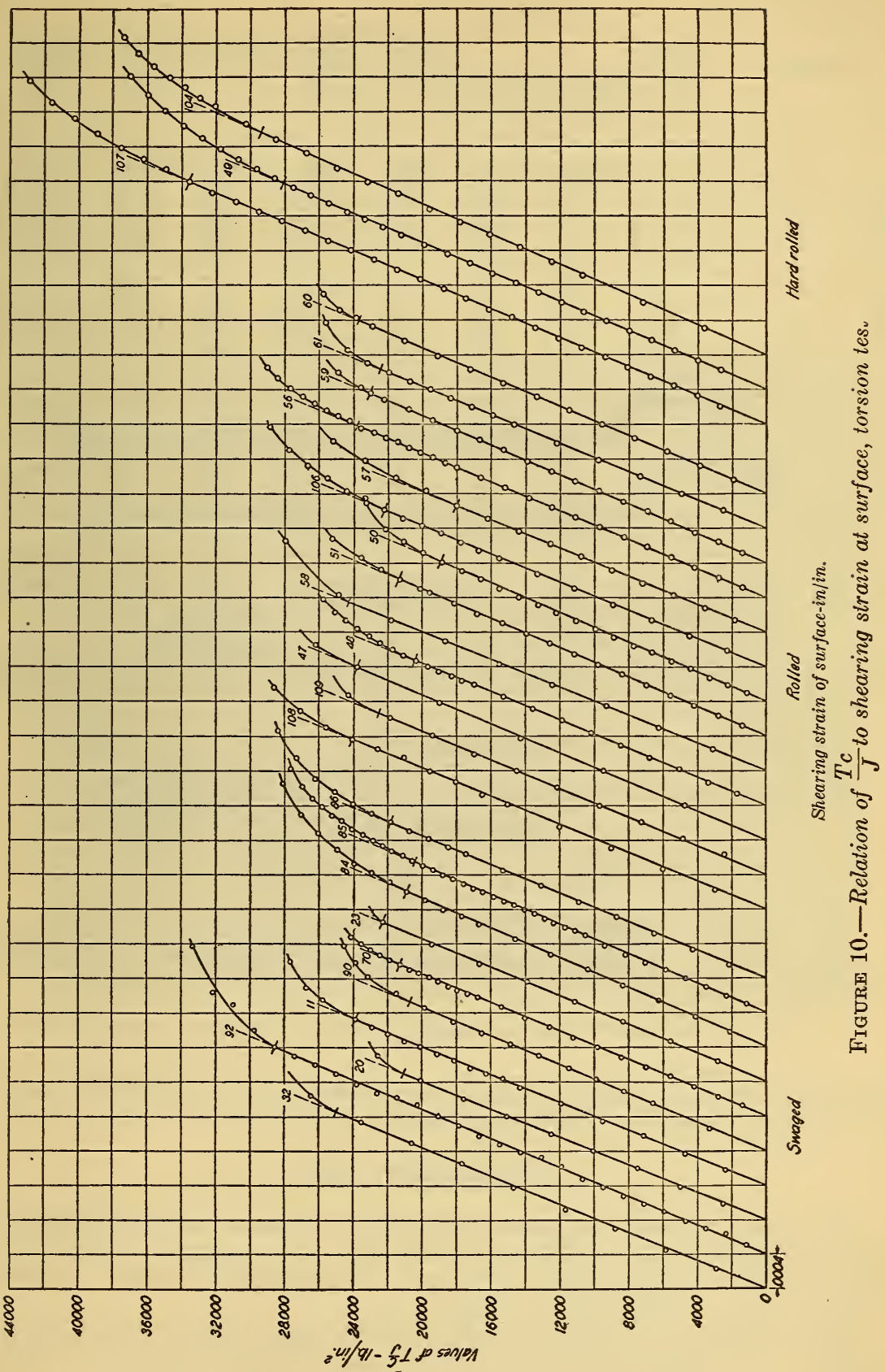


TABLE 5.-Results of torsion tests

\begin{tabular}{|c|c|c|c|c|c|c|c|c|}
\hline \multirow[b]{2}{*}{ Tube No. } & \multirow{2}{*}{$\begin{array}{c}\text { Type of } \\
\text { treat- } \\
\text { ment }\end{array}$} & \multicolumn{2}{|c|}{ Nominal size } & \multirow{2}{*}{$\begin{array}{c}\text { Wall } \\
\text { thickness, } \\
\text { average }\end{array}$} & \multirow{2}{*}{$\begin{array}{c}\text { Torque at } \\
\text { propor- } \\
\text { tional } \\
\text { limit }\end{array}$} & \multirow{2}{*}{$\begin{array}{c}\text { Ultimate } \\
\text { torque }\end{array}$} & \multirow{2}{*}{$\begin{array}{c}\text { Shearing } 1 \\
\text { stress in } \\
\text { extreme } \\
\text { fiber at } \\
\text { propor- } \\
\text { tional } \\
\text { limit }\end{array}$} & \multirow[b]{2}{*}{$\begin{array}{l}\text { Modulus }{ }^{2} \\
\text { of elasticity } \\
\text { in shear }\end{array}$} \\
\hline & & $\begin{array}{c}\text { Outside } \\
\text { diameter }\end{array}$ & $\begin{array}{c}\text { Wall } \\
\text { thickness }\end{array}$ & & & & & \\
\hline $\begin{array}{l}32 \\
108 \\
109 \\
92 \\
20 \\
20\end{array}$ & $\begin{array}{l}\mathrm{B} \\
\mathrm{D} \\
\mathrm{D} \\
\mathrm{B} \\
\mathrm{B}\end{array}$ & $\begin{array}{r}\text { Inches } \\
1 \\
1 \\
1 \\
1 \\
11 / 2\end{array}$ & $\begin{array}{l}\text { Inch } \\
0.049 \\
.049 \\
.065 \\
.065 \\
.065\end{array}$ & $\begin{array}{c}\text { Inch } \\
0.050 \\
.049 \\
.063 \\
.065 \\
.064\end{array}$ & $\begin{array}{r}\text { In.-lb. } \\
1,700 \\
1,600 \\
1,850 \\
2,400 \\
4,200\end{array}$ & $\begin{array}{r}\text { In.-lb. } \\
2,530 \\
2,470 \\
2,500 \\
3,390 \\
6,580\end{array}$ & $\begin{array}{c}\text { Lbs./in. } .^{2} \\
25,020 \\
24,100 \\
22,480 \\
28,620 \\
21,060\end{array}$ & $\begin{array}{l}\text { Lbs./in.2 } \\
12,150,000 \\
12,300,000 \\
12,090,000 \\
11,930,000 \\
12,460,000\end{array}$ \\
\hline $\begin{array}{l}84 \ldots \\
11 . . \\
47-. \\
48 \\
90 .-\end{array}$ & $\begin{array}{l}\mathrm{B} \\
\mathrm{B} \\
\mathrm{D} \\
\mathrm{D} \\
\mathrm{B}\end{array}$ & $\begin{array}{l}13 / 4 \\
2 \\
2 \\
2 \\
2\end{array}$ & $\begin{array}{l}.120 \\
.035 \\
.035 \\
.049 \\
.049\end{array}$ & $\begin{array}{l}.123 \\
.035 \\
.035 \\
.050 \\
.052\end{array}$ & $\begin{array}{r}10,000 \\
5,000 \\
5,000 \\
6,000 \\
6,250\end{array}$ & $\begin{array}{r}17,100 \\
6,540 \\
6,310 \\
9,450 \\
9,940\end{array}$ & $\begin{array}{l}20,880 \\
23,920 \\
23,850 \\
20,400 \\
20,690\end{array}$ & $\begin{array}{l}11,600,000 \\
12,520,000 \\
11,920,000 \\
12,360,000 \\
11,960,000\end{array}$ \\
\hline $\begin{array}{l}70 \ldots \\
51 \\
107 \\
49 \\
4\end{array}$ & $\begin{array}{l}\mathrm{B} \\
\mathrm{D} \\
\mathrm{H} \\
\mathrm{H}\end{array}$ & $\begin{array}{l}2 \\
2 \\
2 \\
2\end{array}$ & $\begin{array}{l}.065 \\
.065 \\
.065 \\
.065\end{array}$ & $\begin{array}{l}.062 \\
.062 \\
.066 \\
.066\end{array}$ & $\begin{array}{r}7,600 \\
7,600 \\
12,500 \\
10,600\end{array}$ & $\begin{array}{l}10,990 \\
10,840 \\
18,020 \\
17,300\end{array}$ & $\begin{array}{l}21,310 \\
21,270 \\
33,530 \\
28,040\end{array}$ & $\begin{array}{l}12,250,000 \\
11,880,000 \\
11,980,000 \\
11,780,000\end{array}$ \\
\hline $\begin{array}{l}50 \ldots \\
106 \\
23 \ldots \\
58 \ldots\end{array}$ & $\begin{array}{l}D \\
D \\
B \\
D\end{array}$ & $\begin{array}{l}2 \\
2 \\
21 / 4 \\
21 / 2\end{array}$ & $\begin{array}{l}.083 \\
.083 \\
.049 \\
.035\end{array}$ & $\begin{array}{l}.081 \\
.081 \\
.048 \\
.034\end{array}$ & $\begin{array}{r}8,500 \\
10,000 \\
8,000 \\
7,800\end{array}$ & $\begin{array}{r}13,740 \\
16,400 \\
9,560 \\
9,610\end{array}$ & $\begin{array}{l}18,870 \\
22,200 \\
22,270 \\
24,300\end{array}$ & $\begin{array}{l}11,940,000 \\
12,330,000 \\
12,040,000 \\
12,530,000\end{array}$ \\
\hline $\begin{array}{l}57 \\
104 \\
56 \\
59 \\
59\end{array}$ & $\begin{array}{l}\mathrm{D} \\
\mathrm{H} \\
\mathrm{D} \\
\mathrm{D}\end{array}$ & $\begin{array}{l}21 / 2 \\
21 / 2 \\
21 / 2 \\
21 / 2\end{array}$ & $\begin{array}{l}.065 \\
.065 \\
.083 \\
.083\end{array}$ & $\begin{array}{l}.051 \\
.061 \\
.081 \\
.081\end{array}$ & $\begin{array}{l}10,000 \\
16,500 \\
17,200 \\
16,600\end{array}$ & $\begin{array}{l}17,730 \\
25,050 \\
25,960 \\
23,190\end{array}$ & $\begin{array}{l}17,940 \\
29,360 \\
23,750 \\
22,980\end{array}$ & $\begin{array}{l}12,370,000 \\
11,470,000 \\
12,000,000 \\
11,720,000\end{array}$ \\
\hline $\begin{array}{l}85-- \\
86-- \\
61- \\
60-\end{array}$ & $\begin{array}{l}\mathrm{B} \\
\mathrm{B} \\
\mathrm{D} \\
\mathrm{D}\end{array}$ & $\begin{array}{l}21 / 2 \\
23 / 4 \\
3 \\
3\end{array}$ & $\begin{array}{l}.095 \\
.083 \\
.065 \\
.083\end{array}$ & $\begin{array}{l}.097 \\
.084 \\
.062 \\
.080\end{array}$ & $\begin{array}{l}17,400 \\
20,000 \\
18,400 \\
24,800\end{array}$ & $\begin{array}{l}32,750 \\
33,870 \\
25,920 \\
33,600\end{array}$ & $\begin{array}{l}20,460 \\
21,860 \\
22,430 \\
23,680\end{array}$ & $\begin{array}{l}11,690,000 \\
12,280,000 \\
12,190,000 \\
11,840,000\end{array}$ \\
\hline
\end{tabular}

1 Shearing stress in extreme fiber $S=T c / J$.

2 Modulus of elasticity in Shear $G=S / u$.

\begin{tabular}{|c|c|c|c|}
\hline Symbol & Type of treatment & Symbol & Type of treatment \\
\hline $\begin{array}{l}\text { A.- } \\
\text { B-- } \\
\mathrm{C}_{--}\end{array}$ & $\begin{array}{l}\text { As-welded. } \\
\text { Swaged. } \\
\text { Swaged-annealed. }\end{array}$ & D & $\begin{array}{l}\text { Rolled. } \\
\text { Cut-burr. } \\
\text { Hard-rolled. }\end{array}$ \\
\hline
\end{tabular}

The modulus of elasticity in torsion may be calculated from the formula

$$
\dot{G}=\frac{S}{u}
$$

in which $G$ is the modulus of elasticity, $S$ the proportional limit, and $u$ the shearing strain at the proportionai limit.

\section{HYDROSTATIC TEST}

This test was made on tubes 1 inch and 2 inches in outside diameter, because tubes of these sizes are made in a wide range of wall thicknesses and in all types of treatment. The specimens were 17 inches long and cut to length with a hack saw.

The fixtures for closing the ends of the 2-inch tubes are shown in Figure 11. Spanner wrenches $A$ are used to screw the shell $F$ over the grip $B$, thereby forcing the inside-tapered ring $C$ over the tapered segments of the grip. The thin ring $D$ is of bronze, which reduces the 
B. S. Journal of Research, RP161

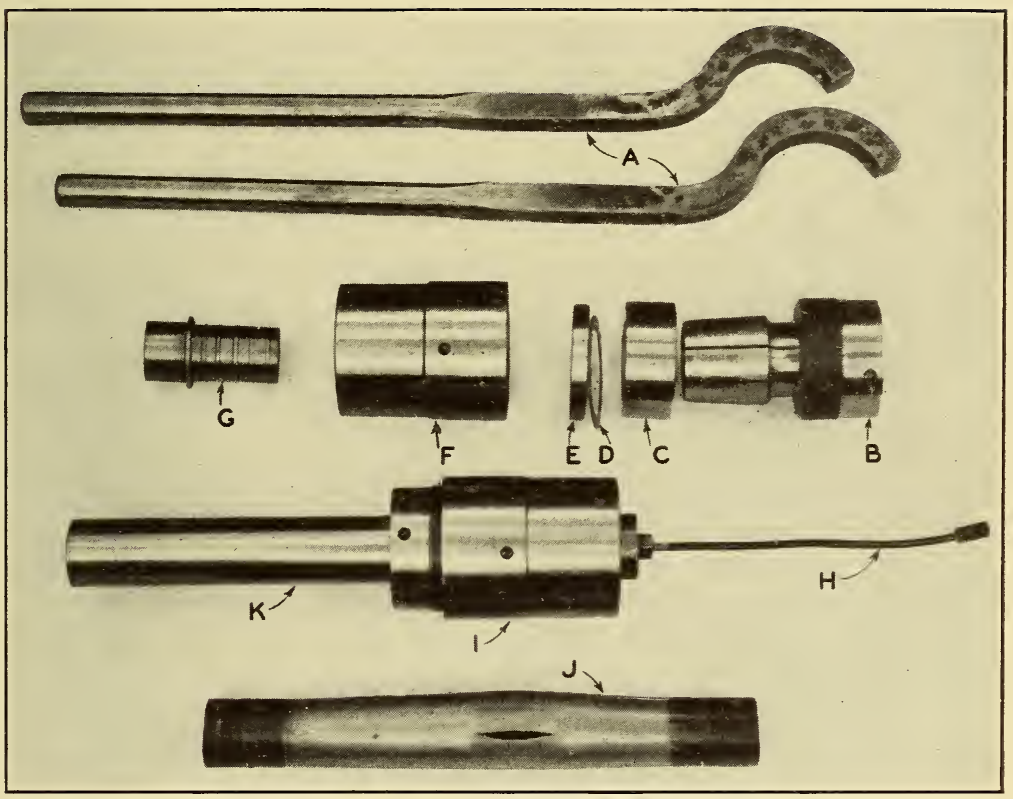

FIGURE 11.-Fixtures for closing the ends of 2-inch tubes for hydrostatic test 
B. S. Journal of Research, RP161

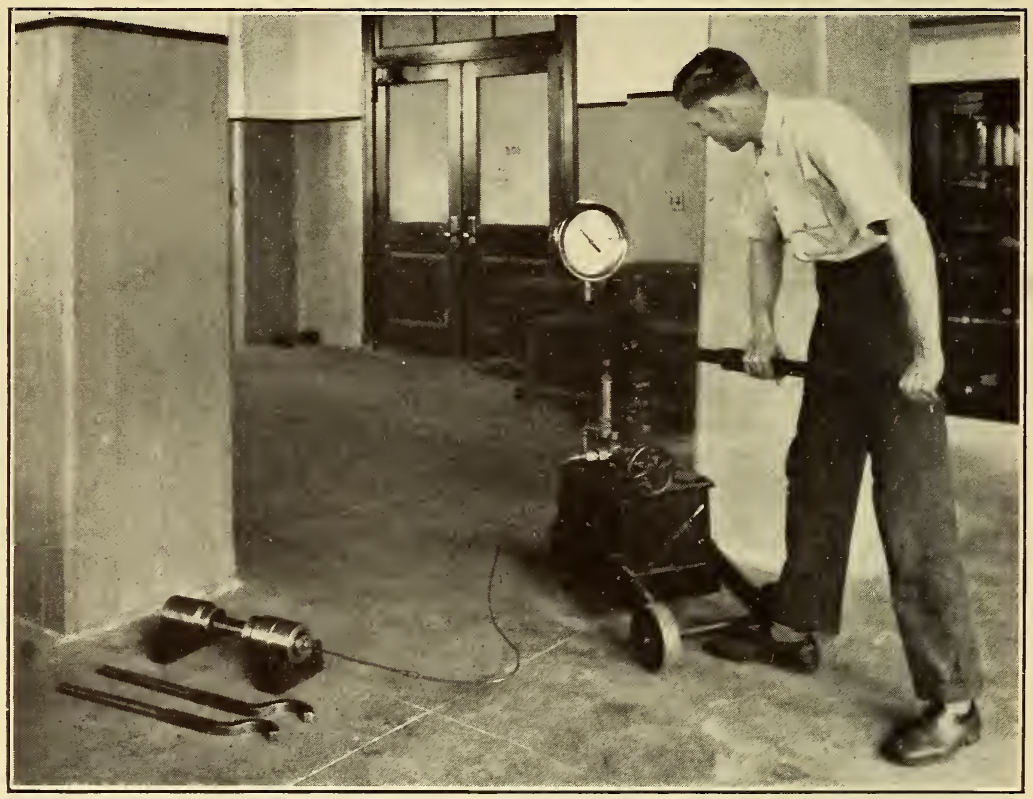

Figure 12.-Hydrostatic testing equipment 
friction, and the ring $E$ is a filler which in effect increases the length of $C$ and bears on a shoulder on the inside of shell $F$. The inside of the segments of grip $B$ have circumferential ribs which fit between the ribs on the solid plug $G$ when in place on the tube. As the shell is screwed over the grip, the wall of the tube is compressed between the segments of grip $C$ and plug $G$, making a tight joint and preventing the plug from slipping. Leaks around the plug are prevented by wrapping a layer of friction tape between the ribs.

The other fixture $I$ is similar and is assembled as shown on specimen $K$. The plug on the inside of the tube has a small hole drilled through its axis and is tapped for a connection with the copper tube $H$ which connects to a pump. Specimen $J$ has been annealed at the ends to make the gripping easier.

The same fixtures were used for testing 1-inch tubes, except that an adapter was fastened on the inside of the 2-inch grips. A different set of plugs was used for each thickness of wall.

After the ends of the specimen were closed, care was taken to fill the specimen with water to remove all the air. The copper tube was then connected to the pump as shown in Figure 12. The pressure was increased slowly until the tube fractured.

A check valve below the pressure gauge retained the maximum pressure on the gauge and prevented rapid return of the needle when the tube fractured. A release valve was used to release the pressure on the gauge. 'The rated capacity of the pump was $10,000 \mathrm{lbs} . / \mathrm{in} .{ }^{2}$.

After the grips were released, the plugs were still held in the tube because the metal had been compressed between the ribs of the plugs. The plugs were removed by pulling them out in a testing machine.

TABLE 6.-Results of hydrostatic test

\begin{tabular}{|c|c|c|c|c|c|c|c|}
\hline \multirow{2}{*}{ Tube No. } & \multirow{2}{*}{$\begin{array}{l}\text { Type of } \\
\text { treat- } \\
\text { ment }\end{array}$} & \multicolumn{2}{|c|}{ Nominal size } & \multirow{2}{*}{$\begin{array}{l}\text { Wall } \\
\text { thick- } \\
\text { ness, } \\
\text { average }\end{array}$} & \multirow{2}{*}{$\begin{array}{l}\text { Maxi- } \\
\text { mum } \\
\text { hydro- } \\
\text { static } \\
\text { pressure }\end{array}$} & \multirow{2}{*}{$\begin{array}{l}\text { Bursting } \\
\text { strength }\end{array}$} & \multirow{2}{*}{$\begin{array}{l}\text { Distance } \\
\text { between } \\
\text { fracture } \\
\text { and weld }\end{array}$} \\
\hline & & $\begin{array}{c}\text { Outside } \\
\text { diameter }\end{array}$ & $\begin{array}{c}\text { Wall } \\
\text { thickness }\end{array}$ & & & & \\
\hline $\begin{array}{l}34-. . \\
35-. \\
43-1 \\
63-\ldots \\
97-\ldots\end{array}$ & $\begin{array}{l}\mathrm{A} \\
\mathrm{B} \\
\mathrm{D} \\
\mathrm{A} \\
\mathrm{A}\end{array}$ & $\begin{array}{r}\text { Inches } \\
1 \\
1 \\
1 \\
1 \\
1\end{array}$ & $\begin{array}{l}\text { Inch } \\
0.028 \\
.028 \\
.028 \\
.035 \\
.035\end{array}$ & $\begin{array}{l}\text { Inch } \\
0.028 \\
.028 \\
.030 \\
.034 \\
.032\end{array}$ & $\begin{array}{r}\text { Lbs./in.2 } \\
3,500 \\
3,700 \\
4,000 \\
4,200 \\
4,400\end{array}$ & $\begin{array}{r}\text { Lbs./in.2 } \\
60,950 \\
62,550 \\
62,850 \\
59,900 \\
66,500\end{array}$ & $\begin{array}{r}\text { Inches } \\
0.62 \\
.53 \\
1.20 \\
.15 \\
.25\end{array}$ \\
\hline $\begin{array}{l}76 \\
64 \\
77-\ldots 8 \\
98 \\
78\end{array}$ & $\begin{array}{l}\mathbf{E} \\
\mathbf{B} \\
\mathbf{B} \\
\mathbf{B} \\
\mathbf{O}\end{array}$ & $\begin{array}{l}1 \\
1 \\
1 \\
1 \\
1\end{array}$ & $\begin{array}{l}.035 \\
.035 \\
.035 \\
.035 \\
.035\end{array}$ & $\begin{array}{l}.034 \\
.034 \\
.034 \\
.032 \\
.036\end{array}$ & $\begin{array}{l}4,400 \\
4,500 \\
4,700 \\
4,600 \\
3,000\end{array}$ & $\begin{array}{l}62,100 \\
61,900 \\
64,400 \\
67,250 \\
38,800\end{array}$ & $\begin{array}{l}1.55 \\
1.48 \\
1.50 \\
1.43 \\
0\end{array}$ \\
\hline $\begin{array}{l}44 \ldots \\
31-\ldots \\
32-\cdots \\
33-\cdots \\
108-\ldots\end{array}$ & $\begin{array}{l}\mathbf{D} \\
\mathbf{A} \\
\mathbf{B} \\
\mathbf{D} \\
\mathbf{D}\end{array}$ & $\begin{array}{l}1 \\
1 \\
1 \\
1 \\
1\end{array}$ & $\begin{array}{l}.035 \\
.049 \\
.049 \\
.049 \\
.049\end{array}$ & $\begin{array}{l}.036 \\
.048 \\
.050 \\
.050 \\
.049\end{array}$ & $\begin{array}{l}4,600 \\
6,100 \\
6,900 \\
5,800 \\
6,600\end{array}$ & $\begin{array}{l}59,300 \\
59,200 \\
62,300 \\
52,350 \\
60,750\end{array}$ & $\begin{array}{r}1.27 \\
.30 \\
.40 \\
.40 \\
1.05\end{array}$ \\
\hline 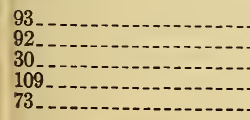 & $\begin{array}{l}\mathrm{A} \\
\mathrm{B} \\
\mathrm{C} \\
\mathrm{D} \\
\mathrm{E}\end{array}$ & $\begin{array}{l}1 \\
1 \\
1 \\
1 \\
1\end{array}$ & $\begin{array}{l}.065 \\
.065 \\
.065 \\
.065 \\
.083\end{array}$ & $\begin{array}{l}.064 \\
.065 \\
.065 \\
.063 \\
.080\end{array}$ & $\begin{array}{r}8,400 \\
9,300 \\
6,900 \\
7,500 \\
11,000\end{array}$ & $\begin{array}{l}59,250 \\
62,200 \\
46,350 \\
52,200 \\
59,700\end{array}$ & $\begin{array}{l}0^{.60} \\
0^{1.14} \\
1.14\end{array}$ \\
\hline $\begin{array}{l}74-15 \\
75 \\
109 \\
11\end{array}$ & $\begin{array}{l}\mathrm{B} \\
\mathrm{C} \\
\mathrm{A} \\
\mathrm{E} \\
\mathrm{B}\end{array}$ & $\begin{array}{l}1 \\
1 \\
2 \\
2 \\
2\end{array}$ & $\begin{array}{l}.083 \\
.083 \\
.035 \\
.035 \\
.035\end{array}$ & $\begin{array}{l}.082 \\
.081 \\
.036 \\
.034 \\
.037\end{array}$ & $\begin{array}{r}11,500 \\
9,500 \\
2,300 \\
1,900 \\
2,500\end{array}$ & $\begin{array}{l}58,600 \\
49,150 \\
62,700 \\
55,000 \\
65,150\end{array}$ & $\begin{array}{l}\text { (1) } \\
0 \\
.25 \\
2.85 \\
.25\end{array}$ \\
\hline
\end{tabular}

1 The pressure required to produce fracture was above the capacity of the pump. 
TABLE 6.-Results of hydrostatic test-Continued

\begin{tabular}{|c|c|c|c|c|c|c|c|}
\hline \multirow{2}{*}{ Tube No. } & \multirow{2}{*}{$\begin{array}{l}\text { Type of } \\
\text { treat- } \\
\text { ment }\end{array}$} & \multicolumn{2}{|c|}{ Nominal size } & \multirow{2}{*}{$\begin{array}{l}\text { Wall } \\
\text { thick- } \\
\text { ness, } \\
\text { average }\end{array}$} & \multirow{2}{*}{$\begin{array}{l}\text { Maxi- } \\
\text { mum } \\
\text { hydro- } \\
\text { static } \\
\text { pressure }\end{array}$} & \multirow{2}{*}{$\begin{array}{l}\text { Bursting } \\
\text { strength }\end{array}$} & \multirow{2}{*}{$\begin{array}{l}\text { Distance } \\
\text { between } \\
\text { fracture } \\
\text { and weld }\end{array}$} \\
\hline & & $\begin{array}{l}\text { Outside } \\
\text { diameter }\end{array}$ & $\begin{array}{c}\text { Wall } \\
\text { thickness }\end{array}$ & & & & \\
\hline $\begin{array}{l}12 \\
47- \\
91 \\
90\end{array}$ & $\begin{array}{l}\mathrm{C} \\
\mathrm{D} \\
\mathrm{A} \\
\mathrm{B} \\
\mathrm{D}\end{array}$ & $\begin{array}{r}\text { Inches } \\
2 \\
2 \\
2 \\
2 \\
2\end{array}$ & $\begin{array}{c}\text { Inch } \\
0.035 \\
.035 \\
.049 \\
.049 \\
.049\end{array}$ & $\begin{array}{c}\text { Inch } \\
0.035 \\
.035 \\
.051 \\
.052 \\
.050\end{array}$ & $\begin{array}{r}\text { Lbs./in. }{ }^{2} . \\
1,800 \\
2,300 \\
3,000 \\
3,200 \\
3,200\end{array}$ & $\begin{array}{r}\text { Lb./in.2 } 2 \\
49,700 \\
. \quad 63,600 \\
56,450 \\
58,250 \\
61,050\end{array}$ & $\begin{array}{c}\text { Inches } \\
0 \\
1.91 \\
2.35 \\
0 \\
0\end{array}$ \\
\hline 51--- & $\begin{array}{l}\mathrm{E} \\
\mathrm{B} \\
\mathrm{C} \\
\mathrm{D}\end{array}$ & $\begin{array}{l}2 \\
2 \\
2 \\
2\end{array}$ & $\begin{array}{l}.065 \\
.065 \\
.065 \\
.065\end{array}$ & $\begin{array}{l}.062 \\
.062 \\
.063 \\
.062\end{array}$ & $\begin{array}{l}3,800 \\
3,900 \\
3,400 \\
4,000\end{array}$ & $\begin{array}{l}58,600 \\
59,150 \\
50,700 \\
60,500\end{array}$ & $\begin{array}{l}.60 \\
2.42 \\
0 \\
2.15\end{array}$ \\
\hline $\begin{array}{l}49- \\
107 \\
506 \\
106\end{array}$ & $\begin{array}{l}\mathrm{H} \\
\mathrm{H} \\
\mathrm{D} \\
\mathrm{D}\end{array}$ & $\begin{array}{l}2 \\
2 \\
2 \\
2\end{array}$ & $\begin{array}{l}.065 \\
.065 \\
.083 \\
.083\end{array}$ & $\begin{array}{l}.066 \\
.066 \\
.081 \\
.081\end{array}$ & $\begin{array}{l}5,400 \\
5,900 \\
5,000 \\
5,400\end{array}$ & $\begin{array}{l}76,400 \\
83,500 \\
56,750 \\
61,250\end{array}$ & $\begin{array}{l}3.00 \\
.25 \\
2.76 \\
.46\end{array}$ \\
\hline
\end{tabular}

\begin{tabular}{|c|c|c|c|}
\hline Symbol & Type of treatment & Symbol & Type of treatment \\
\hline & \multirow{2}{*}{$\begin{array}{l}\text { As-welded. } \\
\text { Swaged. } \\
\text { Swaged-annealed. }\end{array}$} & & \multirow{2}{*}{$\begin{array}{l}\text { Rolled. } \\
\text { Cut-burr. } \\
\text { Hard-rolled. }\end{array}$} \\
\hline C...- & & E-...- & \\
\hline
\end{tabular}

The bursting strengths, given in Table 6, were calculated from the formula

$$
S=\frac{P d}{2 t}
$$

in which $S$ is the bursting strength, $P$ the bursting pressure, $d$ the inside diameter, and $t$ the wall thickness. The diameter $d$ is the inside diameter of the tube before pressure was applied. On account of the ductility of most of the tubes the diameter $d$ increased considerably before fracture occurred. If the bursting strength had been calculated from the actual diameter just before rupture it would have been higher, but this increase has no structural significance.

In this test there was a combination of longitudinal and transverse stresses, or two tensile stresses at right angles to each other. This condition tends to increase the bursting strength and accounts partly (probably largely) for the increase of bursting strength over the tensile strength of circumferential strips.

The shortest distance, along the circumference, between the fracture and weld is given in Table 6 . Figure 13 shows the positions of the fractures relative to the weld, and Figure 14 shows graphically the bursting strengths and positions of fracture. The concentration of failures on either side of the weld and opposite the weld, as shown in Figure 13, is in accordance with what may be expected from theoretical considerations if the welded portion of the tube has a higher yield point and consequently is stiffer than the rest of the tube 
after plastic deformation begins. ${ }^{4}$ That this condition is a fact is shown (1) by the higher Rockwell numbers in the welded portion, indicating a higher ultimate strength and probably a higher yield point, inasmuch as the material in the welded portion and in the rest of the tube is similar and (2) by the tests on the circumferential strip which yielded outside the welded portion in every case except in the case of the swaged-annealed tubing.

The 2-inch hydrostatic specimens are shown in Figure 15. Some of the 1 and 2 inch hydrostatic specimens are shown in Figures 16 and 17 in greater detail.

\section{TENSILE TEST OF WELD}

This test was made on tubes 2 inches in outside diameter, because this size when cut and opened into a strip would form a specimen long enough for milling a reduced section. (See fig. 18.)

To compare the tensile strength of the base metal and of the welds, similar specimens were prepared, some having no welds, others having welds at the middle of the reduced section.

The tubes were chucked in a lathe and rings $1 \frac{1}{4}$ inches long cut from the end. Some of the rings from each tube were cut at the weld parallel to the axis; others were cut diametrically opposite the weld. The rings were straightened and tensile specimens having a reduced section, three-fourths inch wide, machined from them. These untested specimens are shown in Figure 18 above some of the tested specimens. The burrs on some of the welded specimens from as-welded and cut-burr tubes were ground off to make the thickness of the specimen uniform at the weld. This eliminated any additional strength at the weld due to the increase of cross-sectional area formed by the small burr.

The average tensile strength and the position of fracture are given in Table 7 for comparison with the results of the hydrostatic test of the same tube. Figure 18 shows one welded specimen from each of the tubes tested, excepting tubes 106 and 107.
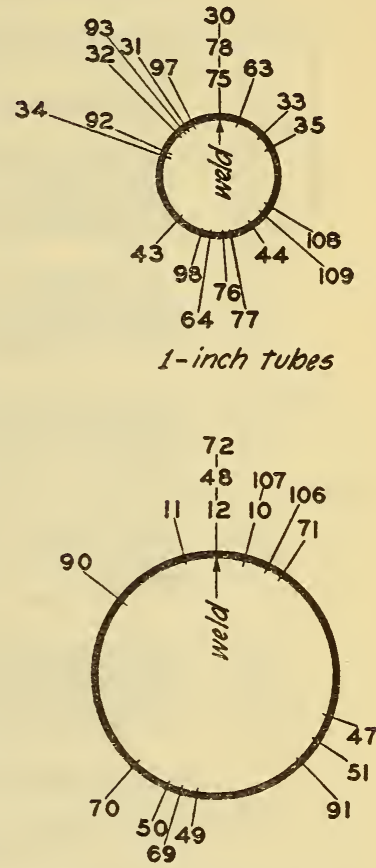

2-inch rubes

Figdre 13.-Diagram showing the location of fractures in hydrostatic specimens

The tube number for each specimen is given on a radial line indicating the location of the fracture with respect to the weld

\begin{tabular}{|c|c|}
\hline Types of treatment & Tube numbers \\
\hline As-welded... & $34,63,97,31,93$, \\
\hline $\begin{array}{l}\text { Cut-burr-..- } \\
\text { Swaged }\end{array}$ & $\begin{array}{l}76,69,71 . \\
64,77,98,32,92 \text {, }\end{array}$ \\
\hline Swaged-annealed_- & $\begin{array}{l}78,33,30,75,12 \text {, } \\
72 .\end{array}$ \\
\hline Hard-rolled_. & $\begin{array}{l}43,44,108,109 \\
\quad 47,48,51,50 \\
106 . \\
49,107 .\end{array}$ \\
\hline
\end{tabular}

4 A. Ostenfeld, Teknisk Elasticitetslaere, 4th ed., Copenhagen, 1924, pp. 518 ff. or A. E. H. Love The Mathematical Theory of Elasticity, 4th ed., Cambridge, 1927, Art. 274, p. 423. $98046^{\circ}-30-3$ 


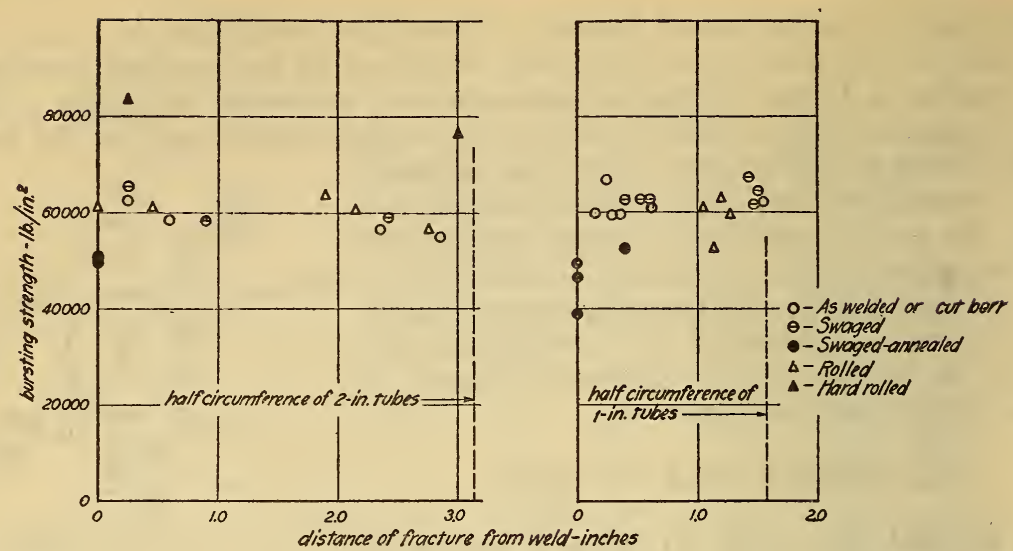

FIGURE 14.-Graph showing the relation of bursting strength to location of fracture, hydrostatic test

TABLE 7.-Results of tensile tests of circumferential strips compared with results of hydrostatic test

\begin{tabular}{|c|c|c|c|c|c|c|c|c|c|}
\hline \multirow{3}{*}{ Tube No. } & \multirow{3}{*}{$\begin{array}{l}\text { Type } \\
\text { of } \\
\text { treat- } \\
\text { ment }\end{array}$} & \multicolumn{2}{|c|}{ Nominal size } & \multirow{3}{*}{$\begin{array}{c}\text { Wall } \\
\text { thick- } \\
\text { ness, } \\
\text { average }\end{array}$} & \multicolumn{4}{|c|}{ Tensile test of circumferential strips } & \multirow{3}{*}{$\begin{array}{l}\text { Hydro- } \\
\text { static } \\
\text { test- } \\
\text { bursting } \\
\text { strength }\end{array}$} \\
\hline & & \multirow{2}{*}{$\begin{array}{c}\text { Outside } \\
\text { diam- } \\
\text { eter }\end{array}$} & \multirow{2}{*}{$\begin{array}{l}\text { Wall } \\
\text { thick- } \\
\text { ness }\end{array}$} & & \multicolumn{2}{|c|}{$\begin{array}{l}\text { Weld outside of } \\
\text { tested section }\end{array}$} & \multicolumn{2}{|c|}{$\begin{array}{l}\text { Weld in center of } \\
\text { tested section }\end{array}$} & \\
\hline & & & & & $\begin{array}{l}\text { Num- } \\
\text { ber } \\
\text { tested }\end{array}$ & $\begin{array}{l}\text { Ultimate } \\
\text { strength, } \\
\text { average }\end{array}$ & $\begin{array}{l}\text { Num- } \\
\text { ber } \\
\text { tested }\end{array}$ & $\begin{array}{l}\text { Ultimate } \\
\text { strength, } \\
\text { average }\end{array}$ & \\
\hline $\begin{array}{l}10 \ldots \\
69 \\
11 \\
12 \ldots\end{array}$ & $\begin{array}{l}\mathrm{A} \\
\mathrm{E} \\
\mathrm{B} \\
\mathrm{C}\end{array}$ & \begin{tabular}{r|} 
Inches \\
2 \\
2 \\
2 \\
2
\end{tabular} & $\begin{array}{l}\text { Inch } \\
0.035 \\
.035 \\
.035 \\
.035\end{array}$ & $\begin{array}{l}\text { Inch } \\
0.036 \\
.034 \\
.037 \\
.035\end{array}$ & $\begin{array}{l}2 \\
2 \\
2 \\
2\end{array}$ & $\begin{array}{r}\text { Lbs./in. }{ }^{2} \\
54,890 \\
45,780 \\
58,920 \\
52,300\end{array}$ & $\begin{array}{r}14 \\
14 \\
4 \\
4\end{array}$ & $\begin{array}{r}\text { Lbs./in. }{ }^{2} \\
54,440 \\
46,960 \\
55,940 \\
246,800\end{array}$ & $\begin{array}{r}\text { Lbs./in. }{ }^{2} \\
62,700 \\
55,000 \\
65,150 \\
249,700\end{array}$ \\
\hline $\begin{array}{l}47 \\
91 \\
90 \\
48\end{array}$ & $\begin{array}{l}\mathrm{D} \\
\mathrm{A} \\
\mathrm{B} \\
\mathrm{D}\end{array}$ & $\begin{array}{l}2 \\
2 \\
2 \\
2\end{array}$ & $\begin{array}{l}.035 \\
.049 \\
.049 \\
.049\end{array}$ & $\begin{array}{l}.035 \\
.051 \\
.052 \\
.050\end{array}$ & $\begin{array}{l}2 \\
2 \\
2 \\
2\end{array}$ & $\begin{array}{l}55,000 \\
50,220 \\
53,150 \\
60,100\end{array}$ & $\begin{array}{r}4 \\
14 \\
4 \\
4\end{array}$ & $\begin{array}{l}58,050 \\
50,970 \\
53,180 \\
60,140\end{array}$ & $\begin{array}{r}63,600 \\
56,450 \\
58,250 \\
261,050\end{array}$ \\
\hline $\begin{array}{l}71--- \\
70--\end{array}$ & $\begin{array}{l}\mathrm{E} \\
\mathrm{B}\end{array}$ & $\begin{array}{l}2 \\
2\end{array}$ & $\begin{array}{l}.065 \\
.065\end{array}$ & .062 & $\begin{array}{l}2 \\
2\end{array}$ & $\begin{array}{l}55,640 \\
53,670\end{array}$ & $\begin{array}{r}14 \\
4\end{array}$ & $\begin{array}{l}53,310 \\
55,280\end{array}$ & $\begin{array}{r}58,600 \\
59,150\end{array}$ \\
\hline 72 & $\mathrm{C}$ & 2 & .065 & .063 & 2 & 52,920 & $\begin{array}{l}2 \\
2\end{array}$ & $\begin{array}{r}49,200 \\
248,410\end{array}$ & 250,700 \\
\hline 51.-. & $\mathrm{D}$ & 2 & .065 & .062 & 2 & 57,700 & 4 & 59,420 & 60,500 \\
\hline $\begin{array}{l}49 \\
107 \\
50 \ldots \\
106\end{array}$ & $\begin{array}{l}\mathrm{H} \\
\mathrm{H} \\
\mathrm{D} \\
\mathrm{D}\end{array}$ & $\begin{array}{l}2 \\
2 \\
2 \\
2\end{array}$ & $\begin{array}{l}.065 \\
.065 \\
.083 \\
.083\end{array}$ & $\begin{array}{l}.066 \\
.066 \\
.081 \\
.081\end{array}$ & $\begin{array}{l}2 \\
1 \\
2 \\
1\end{array}$ & $\begin{array}{l}71,220 \\
83,000 \\
50,650 \\
60,550\end{array}$ & $\begin{array}{l}2 \\
2 \\
4 \\
2\end{array}$ & $\begin{array}{l}71,100 \\
78,920 \\
52,000 \\
60,910\end{array}$ & $\begin{array}{l}76,400 \\
83,500 \\
56,750 \\
61,250\end{array}$ \\
\hline
\end{tabular}

1 The burrs on two of these specimens were ground off to uniform thickness.

2 Fractured in the weld.

\begin{tabular}{|c|c|c|c|}
\hline Symbol & Type of treatment & Symbol & Type of treatment \\
\hline B. & $\begin{array}{l}\text { As-welded. } \\
\text { Swaged. } \\
\text { Swaged-annealed. }\end{array}$ & $\begin{array}{l}\mathrm{D}- \\
\mathrm{E}- \\
\mathrm{H}\end{array}$ & $\begin{array}{l}\text { Rolled. } \\
\text { Cut-burr. } \\
\text { Hard-rolled. }\end{array}$ \\
\hline
\end{tabular}




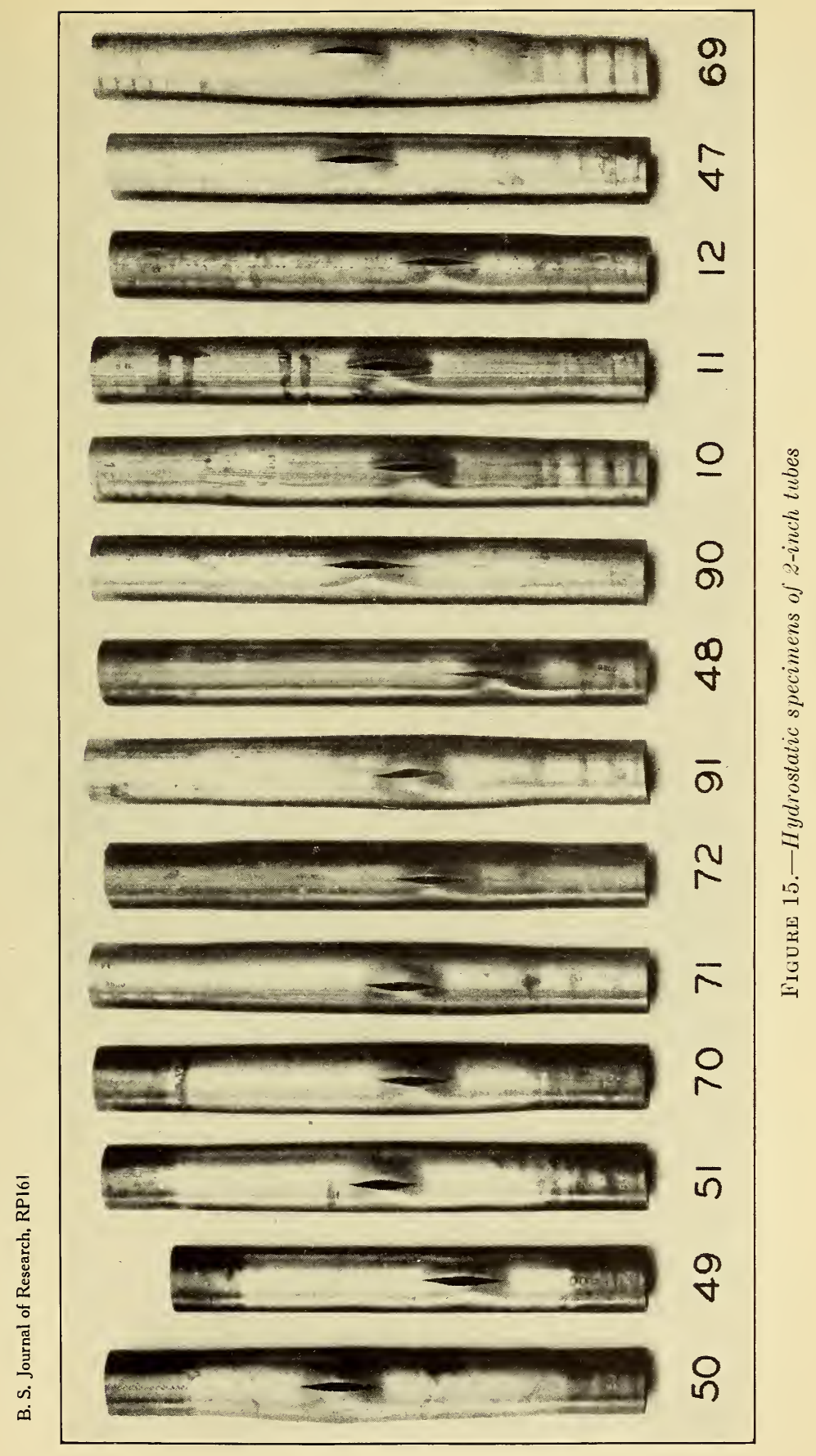


B. S. Journal of Research. RP161

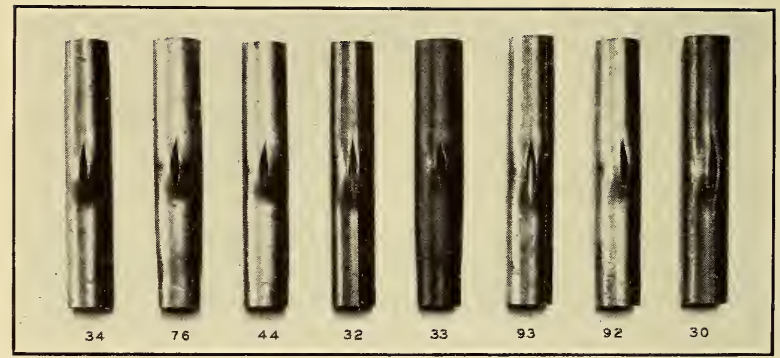

Figure 16.-Fractured portion of some 1-inch hydrostatic specimens

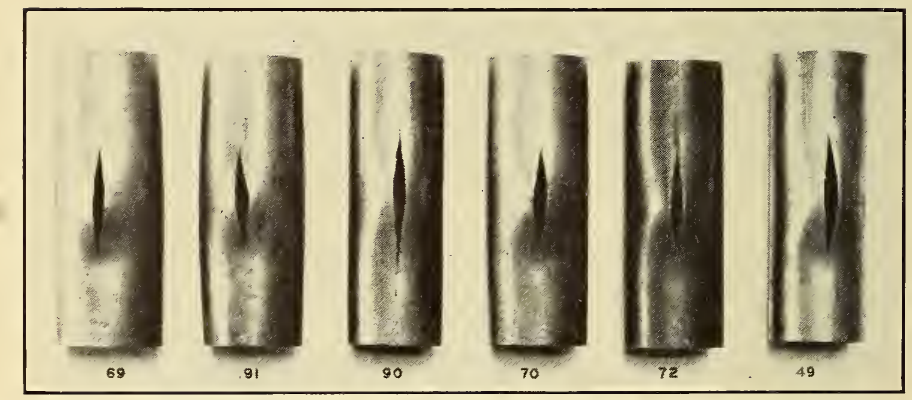

Figure 17.-Fractured portion of some 2-inch hydrostatic specimens 


\section{HARDNESS}

The hardness of the tubing was determined by the Rockwell machine, using a $1 / 16$-inch steel ball and a 100-kg load. About 10 indentations were uniformly distributed around a short specimen cut from the length, one indentation being made on the weld. The average of these Rockwell numbers was taken as the hardness of the tube.

The Rockwell number for each tube is shown in Table 2, and the average Rockwell numbers for the different types of treatment are shown in Table 8.

TABLE 8.-Results of hardness test for the different types of treatment

\begin{tabular}{|c|c|c|c|c|c|}
\hline Types of treatment & $\begin{array}{l}\text { Number } \\
\text { of tubes } \\
\text { tested }\end{array}$ & $\begin{array}{c}\text { Rockwell } \\
\text { No. }\end{array}$ & Types of treatment & $\begin{array}{l}\text { Number } \\
\text { of tubes } \\
\text { tested }\end{array}$ & $\begin{array}{l}\text { Rockwell } \\
\text { No. }\end{array}$ \\
\hline $\begin{array}{l}\text { As-welded. } \\
\text { Cut-burr } \\
\text { Swaged }\end{array}$ & $\begin{array}{r}18 \\
4 \\
24\end{array}$ & $\begin{array}{l}66.6 \\
64.3 \\
72.2\end{array}$ & $\begin{array}{l}\text { Rolled } \\
\text { Hard-rolled-anealed... } \\
\text { Swaged-anno }\end{array}$ & $\begin{array}{r}20 \\
3 \\
19\end{array}$ & $\begin{array}{l}74.1 \\
86.5 \\
54.5\end{array}$ \\
\hline
\end{tabular}

Since high Rockwell numbers were found at the weld, a few specimens of tubing having an outside diameter of 2 inches were selected for a special study of the variation in Rockwell numbers around the tube. The short specimen was cut longitudinally into three segments. Each segment was placed on the bearing block so as to make the indentations on the inside and along a helical line around the tube, the indentations being spaced about one-thirty-second inch circumferentially. The results are shown in Figure 19.

Similar readings were not made upon tubes of other diameters because it was believed that the readings on the 2-inch tubes, having medium thick walls, showed the variations in Rockwell numbers which might be expected in any tubing made by the same process.

\section{FLANGING TEST}

The flanging equipment was designed as recommended in the A. S. T. M. specifications A-83-27 for flanging tests, except that the flaring tool, as shown in Figure 20, was made large enough to form the maximum possible flange on 1 and 2 inch tubes.

Specimens, about $4 \frac{1}{2}$ inches long, were cut from the tube in a lathe. The specimen extended out of the die block (fig. 20) about three-fourths inch when both were resting on a flat surface on the weighing table of the testing machine. The flaring tool was placed in the end of the specimen and forced down by the moving head of the machine until the flare reached the die block. The flaring tool was then removed and the flange was completed by forcing the flared section flat against the die block by means of a flat surface in the moving head of the machine.

If the flange fractured it was cut off as nearly square as possible with a hack saw. Fillers were then placed in the die block to support the specimen on its lathe-cut end and to allow it to extend out of the die block an amount estimated to give a flange without fracture. If the flange did not fracture the same procedure was followed to obtain a larger flange. 

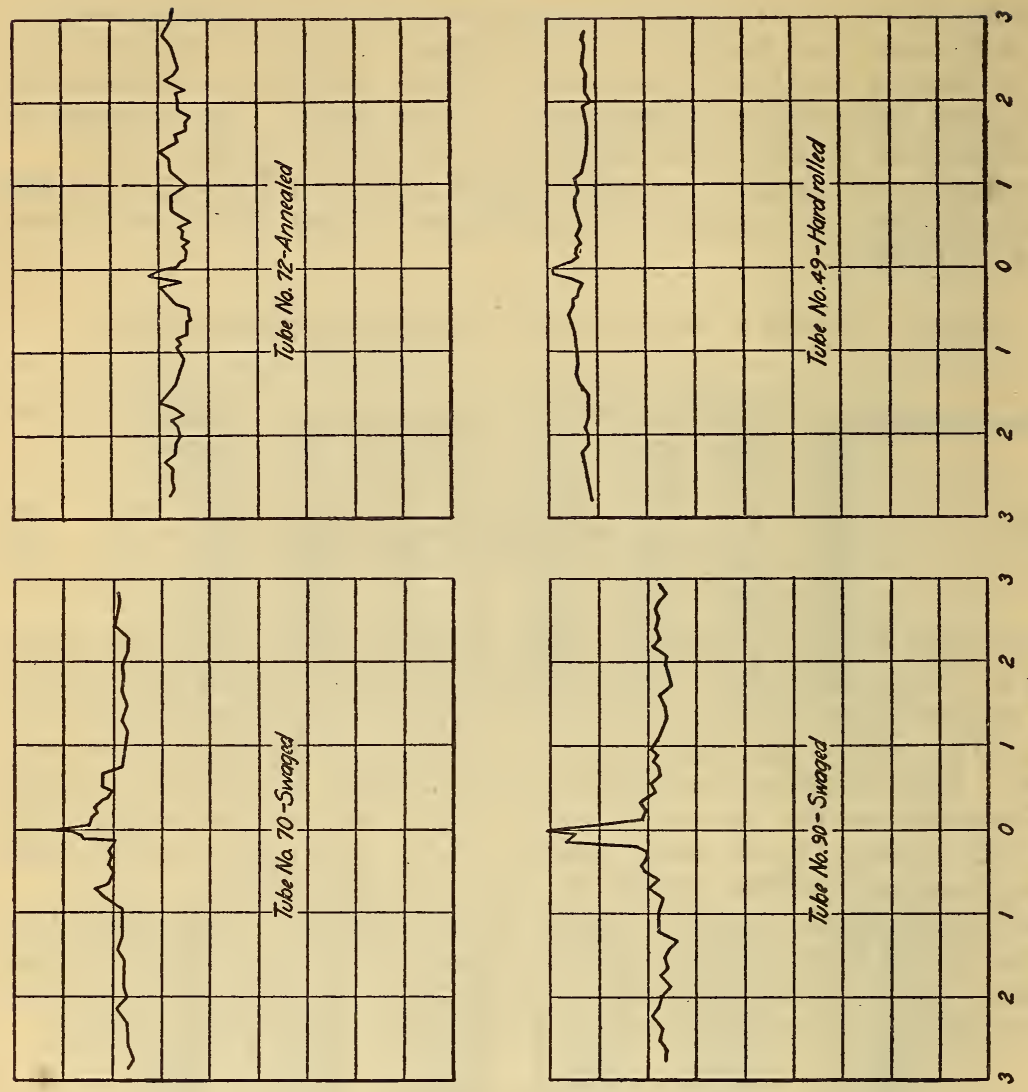

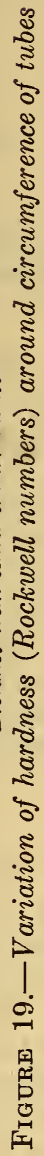
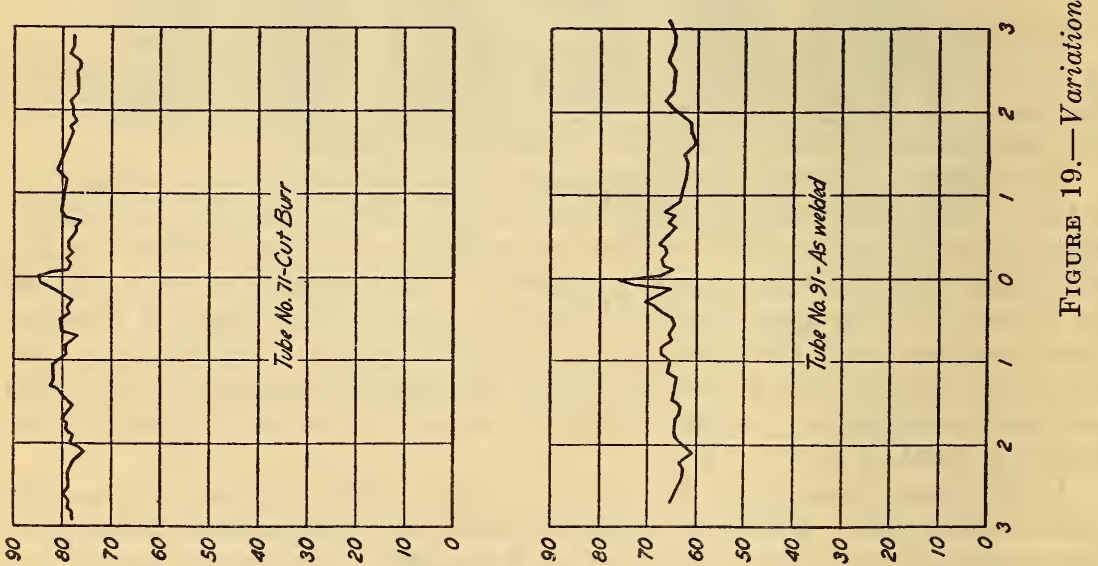


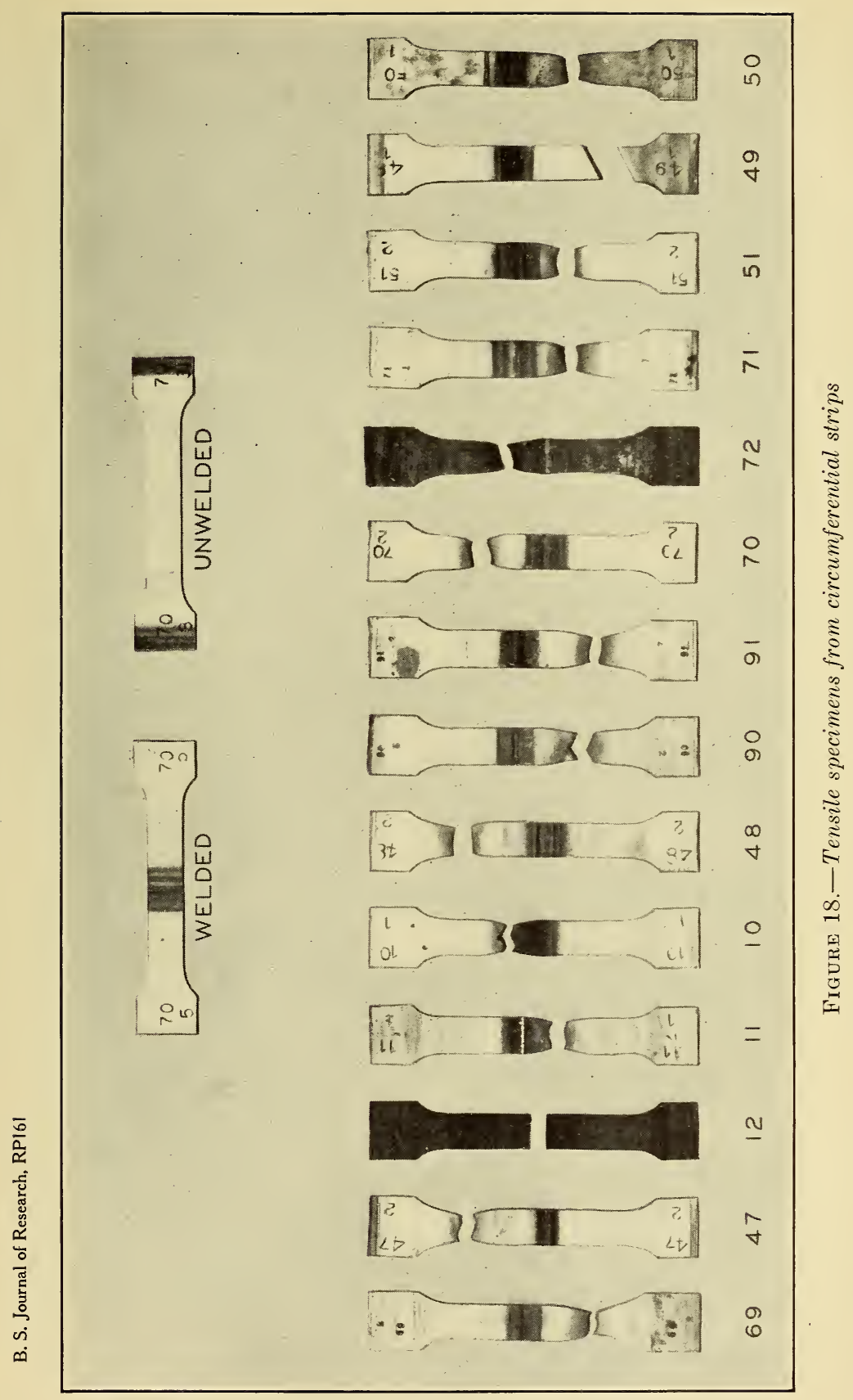




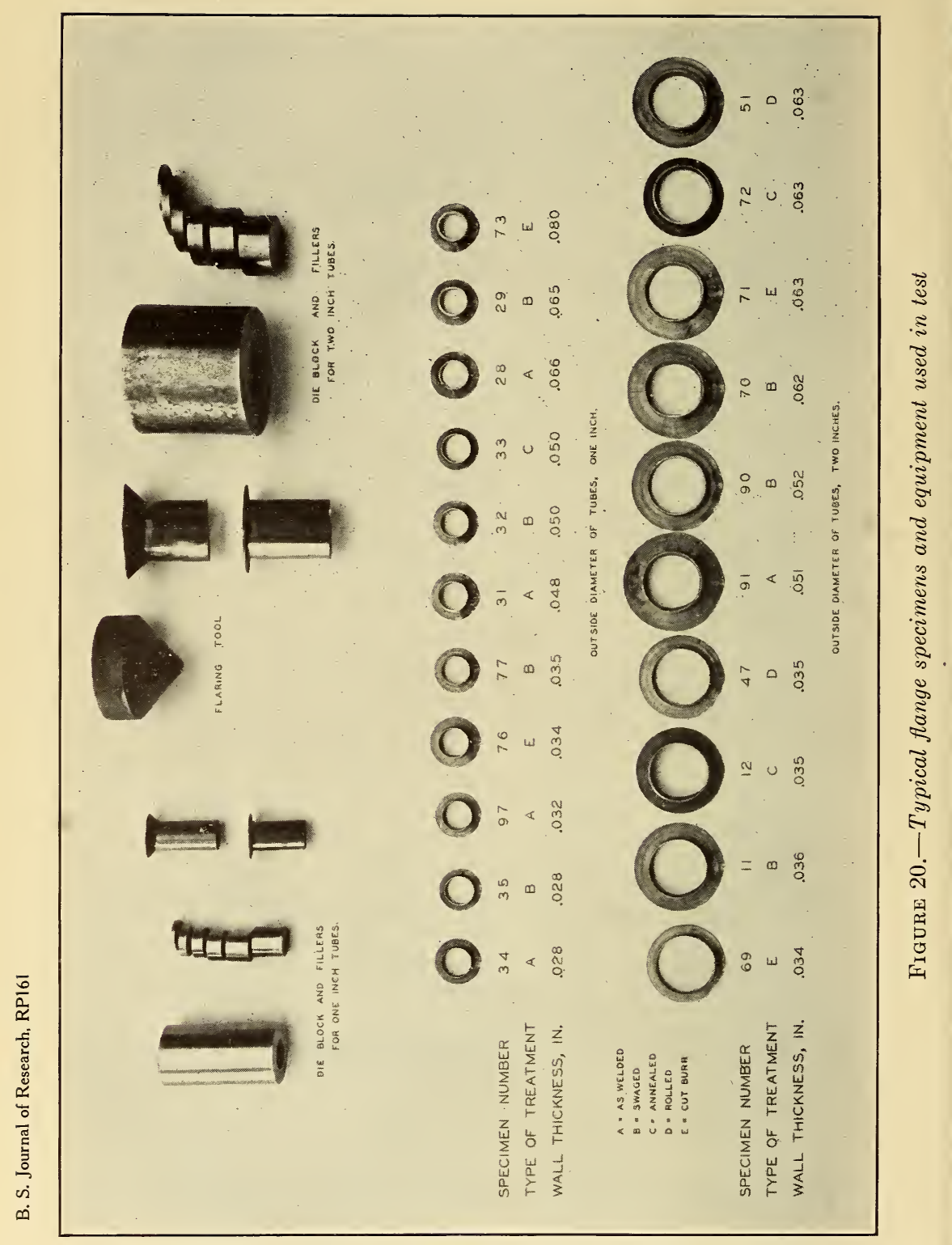


The testing machine was not used to determine the applied load but to obtain a constant speed of 0.44 inch per minute.

Table 9 shows the width of the flange as measured from the outside of the tube. Figure 20 shows some of the typical specimens and the equipment used.

TABLE 9.-Results of flanging test

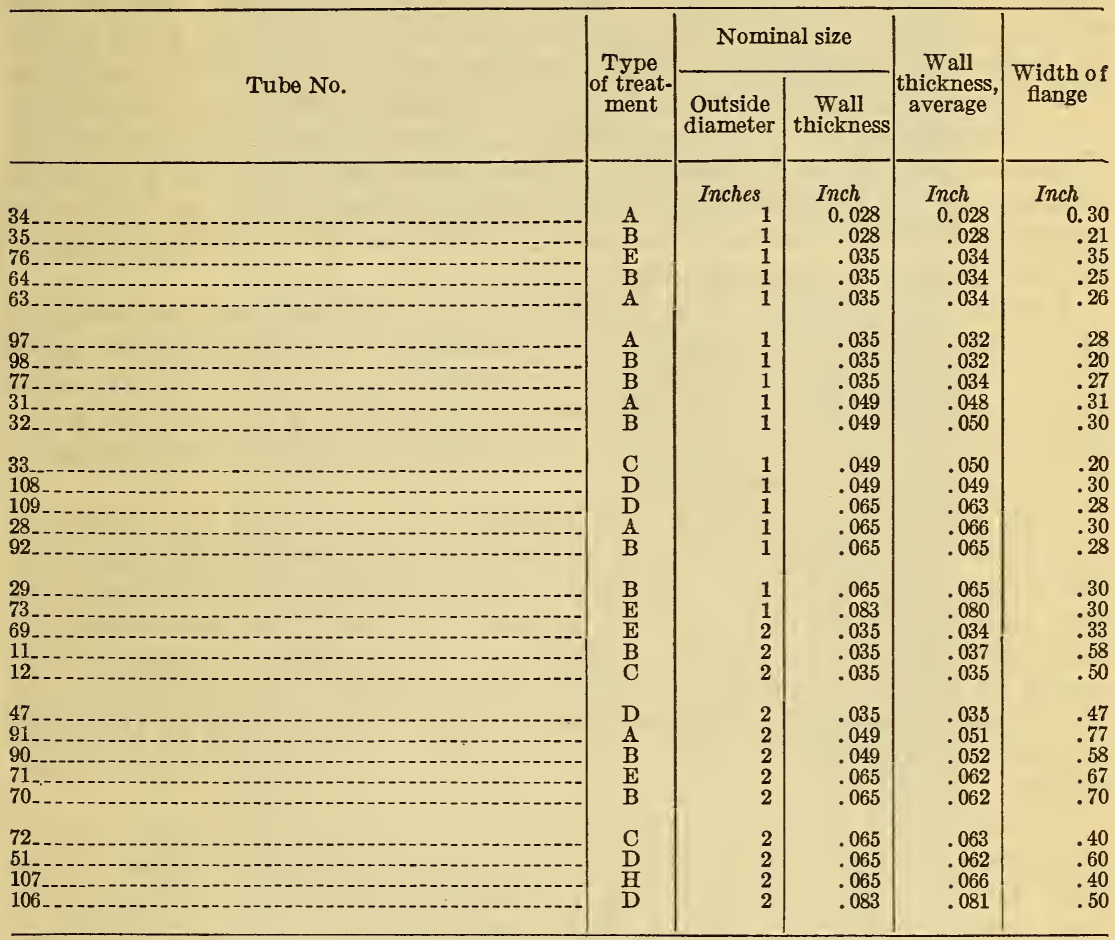

\begin{tabular}{|c|c|c|c|}
\hline Symbol & Type of treatment & Symbol & Type of treatment \\
\hline $\begin{array}{l}\text { A }-. . . \\
\text { B-... } \\
\text { C.... }\end{array}$ & $\begin{array}{l}\text { As-welded. } \\
\text { Swaged. } \\
\text { Swaged-annealed. }\end{array}$ & $\begin{array}{l}\mathrm{D}-\cdots \\
\mathrm{E}-\cdot- \\
\mathrm{H}\end{array}$ & $\begin{array}{l}\text { Rolled. } \\
\text { Cut-burr. } \\
\text { Hard-rolled. }\end{array}$ \\
\hline
\end{tabular}

\section{MICROSCOPIC EXAMINATION}

For the purpose of examining microscopically the structure of the metal of the tubing at the weld and at a distance from the weld, specimens were cut from as-welded, swaged, swaged-annealed, rolled, and hard-rolled tubes. The faces of these specimens corresponding to the cross section of the tubes were polished, etched with a 5 per cent solution of picric acid in alcohol, and examined under the microscope.

Figures 21 to 25, inclusive, are micrographs, taken at the magnifications indicated, showing typical features noted in the microstructure of these specimens and discussed in the following paragraphs. 
The metal at the weld has a distinctly different structure from that outside of the zone affected by the heat of welding, but there is no indication that the metal has been overheated or burned. Figures $21 A, B$, and $C$ show, respectively, the structure of the metal in an as-welded tube specimen at the weld, immediately adjacent to the weld, and the portion of the tube opposite to the weld. The darkcolored patches shown at a low magnification in these micrographs, some as fuzzy masses and others as sharply outlined specks, are carbon-bearing areas. Those areas present at the weld were noted at higher magnifications to be usually grains of sorbitic pearlite. The size of the ferrite grains (colorless) noted in the metal usually at or near the weld, are in some specimens larger than in the base metal. This is apparent in Figure 22. Several specimens showed a decided absence of carbon-bearing areas, even in the portion of the tube opposite to the weld, as illustrated in Figure $22 \mathrm{~B}$. This is sometimes found in low-carbon steel.

Figures $22 A$ and 23 show the line of weld in as-welded and swaged tubes having a wall thickness of 0.065 inch. The mechanical tests show that there was no indication of weakness at the weld even for the tubes the photomicrographs of which showed a line at the weld. In all cases the merging together of the metal at the weld joint appears to have been quite complete.

The annealing following the swaging operation in the swagedannealed tube appears to have removed in a quite effective manner the effect produced by the welding upon the structure of the metal at and near the weld and to have produced a quite uniform structure throughout the tube section. Figure 24 shows the structure of the metal at the weld in a tube having a wall thickness of 0.035 inch; this structure is not much different from that in the portion of the tube opposite to the weld. The 0.065 inch thick tubing showed similar results.

In the rolled tubes the ferrite grains at and near the weld were elongated by the rolling, while those in the portions outside of the weld zone and the area covered by the rolling operation appeared to have been unaffected; that is, they remained more or less equiaxed. Figures $25 A$ and $B$ are typical of these two structures.

\section{DISCUSSION}

\section{VARIATION OF OUTSIDE DIAMETER}

The swaged tubes had the most nearly constant outside diameter, as shown in Figure 3. The maximum difference of the four measurements was 0.008 inch, and 88 per cent of these tubes had a maximum difference of only 0.003 inch.

The maximum difference of outside diameter of the rolled tubes was 0.009 inch, and 78 per cent had a maximum difference of 0.006 inch.

The maximum difference of outside diameter of the swaged-annealed tubes was 0.018 inch, and 85 per cent had a maximum difference of 0.006 inch. 


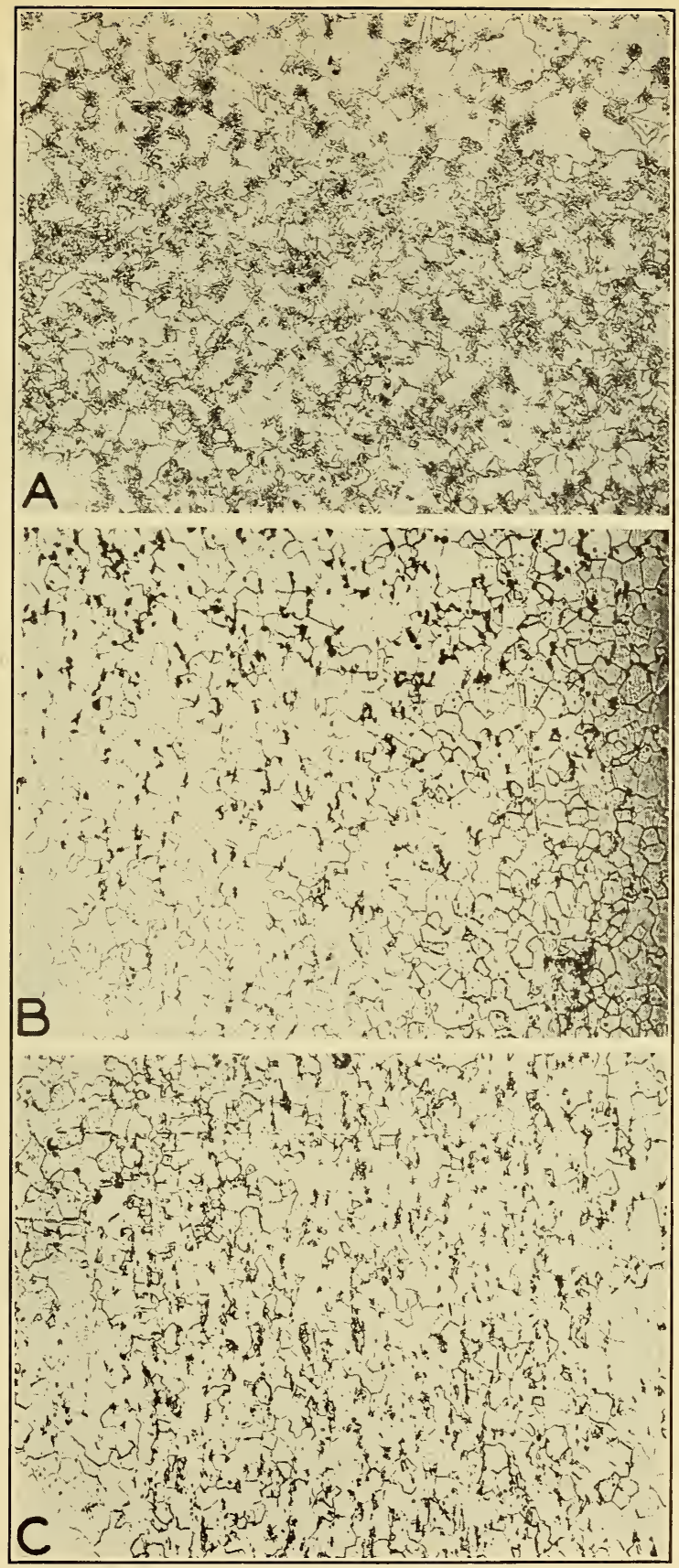

Figure 21.-Microstructure of syecimen of as welded tube, taken at three locations in cross section. $\times 60$

$A$. At the weld. Note the fuzzy dark-appearing patches which are the carbon bearing areas. $B$. Immediately adjacent to the weld. The upper half containing the sharply outlined dark specks is adjacent to the weld. $C$. Opposite to the weld. Normal structure of the unaffected metal. Etchant: 5 per cent solution of picric acid in alcohol (for figs. 21-25, inclusive). (Tube No. 10: 2 inches outside diameter; wall thickness 0.035 inch.) 


\section{B. S. Journal of Research, RP161}

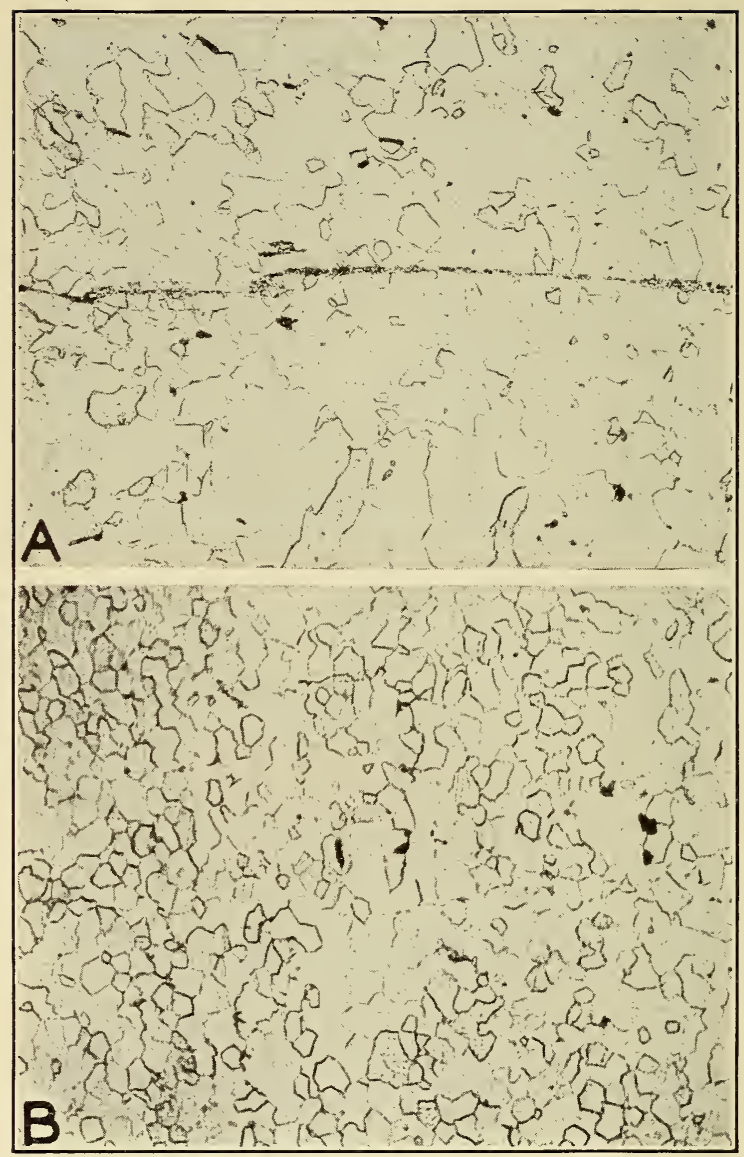

FiguRE 22.-Microstructure of specimen of as welded tube, taken at two locations in cross section. $\times 100$

$A$. At the weld. B. Opposite to the weld. (Tube No. 93: 1 inch outside diameter; wall thickness 0.065 inch.) 


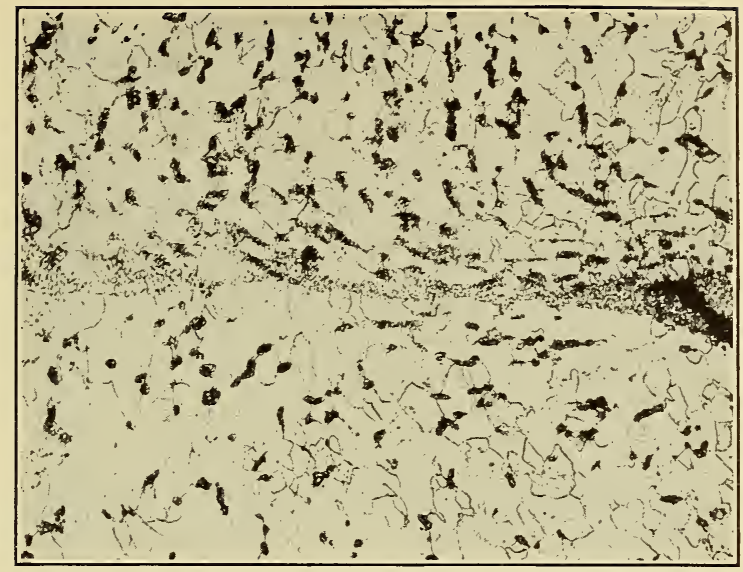

Figure 23.-Microstructure of specimen of swaged tube, taken in cross section at the weld. $\times 100$

Note the apparent distortion of the metal at the line of weld, as evidenced by the arrangement of the dark-colored patches. (Tube No. 92: 1 inch outside diameter; wall thickness 0.065 inch.)

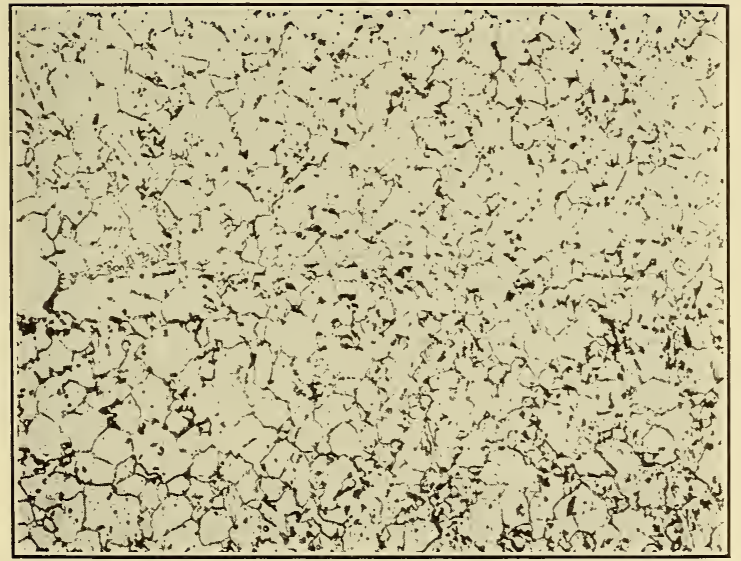

Figure 24.-Microstructure of specimen of swagedannealed tube, taken in cross section at the weld. $\times 100$

The line of weld appears to have been effaced by the annealing treatment following the swaging operation. (Tube No. 12: 2 inches outside diameter; wall thickness 0.035 inch.) 


\section{B. S. Journal of Research, RP161}

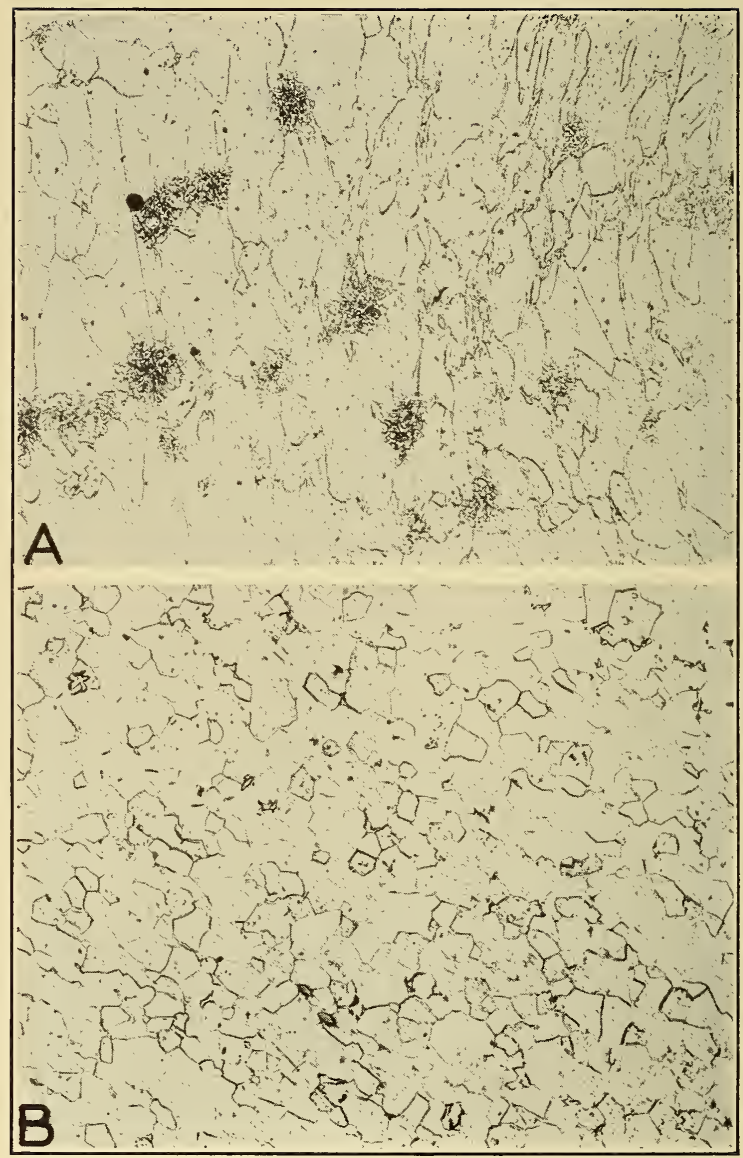

Figure 25.-Microstructure of specimen of rolled tube, taken at two locations in cross section. $\times 100$

$A$. At the weld. $B .90^{\circ}$ from the weld. The ferrite grains at the weld appear deformed while those in the portions away from the weld have been unaffected; that is, are in a more or less equiaxed condition. (Tube No. 108: 1 inch outside diameter; wall thickness 0.049 inch.) 


\section{VARIATION OF THICKNESS OF WALL}

Because of the uniformity of thickness with which strip steel can be rolled, the finished tube will also have this uniformity.

With the exception of the welds in the as-welded, cut-burr, and rolled tubes, but including the weld in swaged and swaged-annealed tubes, the maximum difference in thickness of wall was 0.003 inch; 93 per cent showed a maximum difference of 0.002 inch and 57 per cent a maximum difference of 0.001 inch.

\section{TENSILE TEST OF FULL SECTION}

By varying the cold working a wide range of strengths can be obtained without appreciable change in the carbon content of the steel.

The hard-rolled tubes had, on an average, the highest tensile strength and the lowest elongation. The swaged and the rolled tubes had practically the same tensile strength. The swaged-annealed tubes had a lower tensile strength and a lower ratio of yield point to tensile strength but a considerable increase in elongation. This is shown in Table 3.

\section{AXIAL CRUSHING TEST}

Cracks showed in some of the specimens at the weld on the outside edges of the folds, and these cracks seemed to be due, in most cases, to the difference in ductility between the weld and the base metal.

The hard-rolled tubes, Nos. 104 and 107, had a high ratio of yield point to ultimate strength and a low elongation in the tensile test. In the axial crushing test these specimens failed by leaning over and crinkling locally at the top and the bottom on opposite sides of the specimen. This is probably due to the high ratio of yield point to ultimate strength and low ductility in compression.

\section{TORSION TEST}

In most of the tubes the failure occurred by buckling of the thin wall for a comparatively short distance. This failure is shown in Figure 9 for tubes Nos. 47, 58, and 61, and for these thin tubes may be explained by the compressive stresses on planes making an angle of approximately $45^{\circ}$ with the axis.

In the tubes with thicker walls, for example, tube No. 84, the tube keeps its circular cross section and the specimen twists quite uniformly along its entire length.

The buckling did not begin at the weld of any of the specimens. None of the specimens fractured in the weld or in the base metal.

\section{HYDROSTATIC TEST}

The bursting strength of the tube was higher than the tensile strength of the circumferential strips cut from the tube. This increase of strength is probably due largely to the combination of longitudinal and transverse tensile stresses.

With the exception of the annealed tubes, only one specimen, rolled tube No. 48, fractured in the weld. The bursting strength of this tube was higher than that of a number of other rolled tubes which fractured outside of the weld.

Of the annealed tubes, one specimen, tube No. 33 , fractured outside of the weld. The average bursting strength of the remainder was 
about 90 per cent of the bursting strength of the annealed specimen which did not fracture in the weld. This indicates that the annealing process reduces the strength of the weld about 10 per cent below that of the base metal.

Except for the annealed tubes, the locations of the fractures did not bear any definite relation to the welds. There is therefore no zone of weakness in the tube due to the welding operation.

\section{TENSILE TEST OF WELD}

There was not a complete agreement of the position of fracture in this test with the position in the hydrostatic test. The hydrostatic specimen of tube No. 48 fractured in the weld, and all the circumferential strips fractured outside of the weld.

The fracture did not occur in the weld of any of the strips from aswelded or cut-burr tubes, nor did the fracture occur in the weld of any of the strips with the burrs ground off to make the thickness uniform at the weld. This showed that with the burr removed the weld was equally as strong as other elements of the tube in the reduced section.

The annealed specimens which fractured in the weld had a tensile strength equivalent to about 93 per cent of the base metal as determined by testing strips with the weld outside of the reduced section.

With the weld in the center as well as outside of the reduced section, comparative tensile strengths were obtained around the tube. These strengths did not indicate any zone of weakness near the weld.

\section{HARDNESS}

The curves showing the variation of hardness around the tube indicate that the welding operation slightly increases the hardness at the weld.

The swaging and rolling operations increase the hardness of the tube, and the hardness of the weld is correspondingly increased. There was no decrease of hardness adjacent to the weld of any of the tubes, but an increase at the weld as shown in Figure 19. The hardness at the weld of the annealed tubes is practically the same as the hardness of the tube.

\section{FLANGING TEST}

The width of the flange is not a definite measure of the ductility of the tube at right angles to the axis because of the unknown factors which entered into this test. One of the unknown factors is the friction between the tube and the flaring tool, which seems to vary for the different tubes. Another factor is the compressive strength of the tube, for a number of the tubes started to crinkle below the flaring tool, due to the axial load, before the maximum flange could be formed.

\section{CONCLUSIONS}

This investigation was made for the purpose of determining the physical properties of low carbon steel tubing. The tubing was formed from strip steel and electrically welded under pressure by the resistance method. The tubes varied in outside diameter from five-eighths inch to 3 inches and in wall thickness from 0.028 to 0.120 
inch, inclusive. The results seem to warrant the following conclusions:

1. The maximum difference in the outside diameter of the swaged tubes (four measurements at $45^{\circ}$ intervals) was 0.008 inch, and 88 per cent of these tubes did not exceed 0.003 inch; for the rolled tubes the maximum difference was 0.009 inch, and 78 per cent did not exceed 0.006 inch; for the swaged-annealed tubes the maximum difference was 0.018 inch, and 85 per cent did not exceed 0.006 inch.

2. With the exception of the welds of the as-welded, cut-burr, and rolled tubes, but including the weld of the swaged and swagedannealed tubes, the maximum difference of the four measurements of the wall thickness was 0.003 inch; 93 per cent did not exceed 0.002 inch, and 57 per cent did not exceed 0.001 inch.

3 . For the swaged-annealed tubes the tensile strength was greater than the compressive strength. The average strengths are 51,000 lbs./in. ${ }^{2}$ in tension and $46,000 \mathrm{lbs} . /$ in. $^{2}$ in compression. For the other tubes the strength was practically the same in tension and compression. The average value for as-welded and cut-burr tubes is $54,000 \mathrm{lbs}$./in. ${ }^{2}$, for swaged tubes $58,000 \mathrm{lbs}$./in. ${ }^{2}$, for rolled tubes $56,000 \mathrm{lbs} . / \mathrm{in}^{2}{ }^{2}$, and for hard-rolled tubes $74,000 \mathrm{lbs}$./in. ${ }^{2}$

The average yield point in tension of the as-welded and cut-burr tubes was about 90 per cent of their average tensile strengths (minimum, 76 per cent), swaged tubes about 93 per cent (minimum, 83 per cent), rolled tubes about 91 per cent (minimum, 83 per cent), hardrolled about 95 per cent (minimum, 93 per cent), and swaged-annealed tubes about 71 per cent (minimum, 67 per cent).

The average elongation of as-welded and cut-burr tubes in 2 inches was about 34 per cent and in 8 inches 20 per cent; of swaged tubes in 2 inches 28 per cent and in 8 inches 12 per cent; of rolled tubes in 2 inches 36 per cent and in 8 inches 15 per cent; of hard-rolled in 2 inches 8 per cent and in 8 inches 3 per cent; of swaged-annealed tubes in 2 inches 48 per cent and in 8 inches 31 per cent.

4 . In the torsion test the average shearing stress in the extreme fibers at the proportional limit for the swaged tubes was 22,610 lbs./in. ${ }^{2}$, for the rolled tubes $22,190 \mathrm{lbs}$./in. ${ }^{2}$, and for the hard-rolled tubes $30,310 \mathrm{lbs}$./in. ${ }^{2}$ No fracture occurred in the weld or in the base metal of any of the specimens even when twisting was continued after the ultimate torque was reached.

5. In the hydrostatic test the average bursting strength of 10 aswelded and cut-burr tubes was $60,060 \mathrm{lbs}$./in. ${ }^{2}$, of 9 swaged tubes $62,550 \mathrm{lbs}$./in. ${ }^{2}$, of 9 rolled tubes $59,800 \mathrm{lbs}$./in. ${ }^{2}$, of 2 hard-rolled tubes $79,950 \mathrm{lbs}$./in. ${ }^{2}$, and of 6 swaged-annealed tubes $47,840 \mathrm{lbs}$./in. ${ }^{2}$ The bursting strengths of the tubes which failed near the weld were practically the same as those of the tubes which failed at a distance from the weld. The average bursting strength of the five swagedannealed tubes that fractured in the weld was about 90 per cent of the bursting strength of the tube that fractured outside of the weld.

6 . The average tensile strength of the circumferential strips cut from the tube was practically the same as the longitudinal tensile strength of the tube. An exception to this was the tensile strength of the strips from the two swaged-annealed tubes that fractured in the weld, and the average strength of these was about 93 per cent of the strength of the base metal. 
7. The average Rockwell number, using a $1 / 16$-inch steel ball and a $100-\mathrm{kg}$ load, was about 65 for as-welded and cut-burr tubes, 73 for swaged and rolled tubes, 86 for hard-rolled tubes, and 54 for swagedannealed tubes. There was a gradual increase of hardness near the weld of all tubes excepting the swaged-annealed, which were practically uniform.

8. The microscopic examination showed that there was no overheating or burning of the metal at the weld. The edges at the seam were heated to the welding temperature and immediately forced together. Apparently there are no more inclusions at the weld than in the base metal.

9. This investigation shows that, except in the case of swagedannealed tubing, the properties of the base metal (the metal not affected by the welding operation) can be used in determining the working stresses for different structural uses of tubing made by the process used in the manufacture of this electrically welded tubing, no allowance being necessary for the altered structure in and adjacent to the weld. The properties at and near the weld for annealed tubing are sometimes slightly lower than the properties for the base metal.

Washington, July 15, 1929. 